DE ECONOMIST 157, NO. 2, 2009

\title{
SYSTEMIC RISK IN THE FINANCIAL SECTOR: AN ANALYSIS OF THE SUBPRIME-MORTGAGE FINANCIAL CRISIS**
}

\author{
BY
}

\author{
MARTIN F. HELLWIG*
}

\begin{abstract}
Summary
The paper analyses the causes of the current crisis of the global financial system, with particular emphasis on the systemic elements that turned the crisis of subprime mortgage-backed securities in the United States, a small part of the overall system, into a worldwide crisis. The first half of the paper explains the role of mortgage securitization as a mechanism for allocating risks from real estate investments and discusses what has gone wrong and why in the implementation of this mechanism in the United States. The second half of the paper discusses the incidence of systemic risk in the crisis. Two elements of systemic risk are identified. First, there was excessive maturity transformation through conduits and structured-investment vehicles (SIVs); when this broke down in August 2007, the overhang of asset-backed securities that had been held by these vehicles put significant additional downward pressure on securities prices. Second, as the financial system adjusted to the recognition of delinquencies and defaults in US mortgages and to the breakdown of maturity transformation of conduits and SIVs, the interplay of market malfunctioning or even breakdown, fair value accounting and the insufficiency of equity capital at financial institutions, and, finally, systemic effects of prudential regulation created a detrimental downward spiral in the overall financial system. The paper argues that these developments have not only been caused by identifiably faulty decisions, but also by flaws in financial system architecture. In thinking about regulatory reform, one must therefore go beyond considerations of individual incentives and supervision and pay attention to issues of systemic interdependence and transparency.
\end{abstract}

Key words: mortgage securitization, subprime-mortgage financial crisis, systemic risk, banking regulation, capital requirements

JEL Code(s): G01, G29, G32

* Corresponding author: Max Planck Institute for Research on Collective Goods, Kurt Schumacher Strasse 10, 53113 Bonn, Germany; e-mail: hellwig@coll.mpg.de.

** Revised and expanded text of the Jelle Zijlstra Lecture at the Free University of Amsterdam on May 27, 2008. I am very grateful to the Jelle Zijlstra Professorial Fellowship Foundation for inviting me to visit the Netherlands as Jelle Zijlstra Professorial Fellow 2008 and to the Netherlands Institute for Advanced Study for providing a wonderful environment for this visit. This expanded text tries to respond to comments and questions from the discussant, Gerrit Zalm, and from members of the audience at the Lecture, for which I am very grateful. I am also grateful for comments on this text from Christoph Engel. Kristoffel Grechenig, Hans-Jürgen Hellwig, Isabel Schnabel, and two referees. As the text was being written, its subject itself has been evolving at a catastrophic pace. Some anachronisms are therefore unavoidable. However, the core of the analysis is, I believe, unaffected. 


\section{INTRODUCTION}

Since August 2007, financial markets and financial institutions all over the world have been hit by catastrophic developments that had started earlier in 2007 with problems in the performance of subprime mortgages in the United States. Financial institutions have written off losses worth many billions of dollars, Euros or Swiss francs, and are continuing to do so. Liquidity has virtually disappeared from important markets. Stock markets have plunged. Central banks have provided support on the order of hundreds of billions, intervening not only to support the markets but also to prevent the breakdown of individual institutions. At last, governments in the United States and Europe are stepping in to support financial institutions on a gigantic scale.

Because of their losses, many financial institutions have been forced to recapitalize; others have gone under, some of them outright and some by being taken over by other, presumably healthier institutions. Among the affected institutions, we find some that had been deemed to be at the forefront of the industry in terms of profitability and in terms of their competence in risk management, as well as some whose viability had been questioned even before the crisis. As yet, it is not clear how far the crisis will go.

Public reaction to these developments has mainly focussed on moral hazard of bank managers. Sheer greed, so the assessment goes, led them to invest in mortgage-backed securities, exotic financial instruments that they failed to understand, and to disregard risks when the very term "subprime lending" should have alerted them to the speculative nature of these assets. As the crisis developed, their lack of forthrightness and/or understanding was evidenced by their failure to come clean and write off their losses all at once. They seemed to prefer revealing their losses piecemeal, a few billions one week and another few billions the next.

In absolute terms, the numbers involved seem large. As of April 2008, the International Monetary Fund (IMF) was predicting aggregate losses of 945 billion dollars overall, 565 billion dollars in US residential real-estate lending, and 495 billion dollars from repercussions of the crisis on other securities. By October 2008, the IMF had raised its loss prediction to 1.4 trillion dollars overall, 750 billion dollars in US residential real-estate lending, and 650 billion dollars from repercussions of the crisis on other securities. By September 2007, total reported write-offs of financial institutions are said to have reached 760 billion dollars; global banks alone have written off 580 billion dollars. ${ }^{1}$

In relative terms, the meaning of these numbers is unclear. They seem both, too large and too small, too large relative to the prospective losses from 
actual defaults of subprime mortgage borrowers and too small to explain the worldwide crisis that we are experiencing.

The losses that the IMF predicts for US residential real-estate lending mainly concern mortgage-backed securities (MBS). In particular, non-prime mortgage-backed securities account for some 450 out of 565 billion dollars in the April estimate, 500 out of 750 billion in the October estimate. The outstanding volume of these securities is estimated as 1.1 trillion dollars. The estimates of 450 billion or 500 billion dollars of losses on these 1.1 trillion dollars of outstanding securities correspond to average loss rates of $40-45 \%{ }^{2}$ If the borrower's original equity position was $5 \%,{ }^{3}$ a loss rate of $40-45 \%$ implies a decline in the value of the property by $45-50 \%$. The average actual decline of residential real-estate prices in the United States from their peak in 2006 to the second quarter of 2008 has been around $19 \% .^{4}$ Relative to this number, the IMF's loss estimate seems extraordinarily high. To put the argument in another way: If I assume that price declines will end up at $30 \%$, rather than $50 \%$, with a $5 \%$ equity share of borrowers, I get a $25 \%$ loss rate, for a total loss of 275 billion dollars on the total 1.1 trillion dollars of outstanding nonprime securities. This is still a substantial number, but significantly smaller than the IMF's estimate of 500 billion dollars.

The IMF's estimates of losses on mortgage-backed securities are not actually based on estimates of the incidence of borrower defaults. ${ }^{5}$ These estimates reflect declines in market valuations. In well functioning markets, we would expect these valuations to reflect expectations of future debt service. However, since August 2007, markets have not been functioning well. For some securities, indeed, they have not been functioning at all; in these cases, the losses reflect expectations of what the market valuations would be if markets were

2 According to the IMF's Global Financial Stability Report of April 2008 (2008a), mortgagebacked securities as such were subject to a discount of $30 \%$ in the market and MBS collateralized debt obligations (MBS CDOs) subject to a discount of $60 \%$. When applying these ratios to the outstanding 400 billion dollars of MBS CDOs and to the $1100-400=700$ billion dollars of mortgage-backed securities that are not accounted for by MBS CDOs, one obtains the IMF's loss estimates of 240 billion and 210 billion for these two sets of securities, for a total of 450 billion dollars. In the Global Financial Stability Report of October 2008, the discount for MBS CDOs has been raised to $72.5 \%$; and the loss estimates have risen accordingly.

3 The actual down payment rate in subprime mortgage contracts was $6 \%$ on average, in AltA mortgage contracts $12 \%$ on average. For mortgage contracts concluded in 2004 or 2005, the property appreciation that occurred until the summer of 2006 would provide an additional buffer.

4 According to the S\&P/Case-Shiller U.S. National Home Price Index; see indices at http:// www.standardandpoors.com.

5 As of the first quarter of 2008, the delinquency rate, i.e., the share of mortgages with payments outstanding 90 or more days, was $6.35 \%$ altogether, the foreclosure rate $2.47 \%$ (Mortgage Bankers Association, http://www.mortgagebankers.org/NewsandMedia/PressCenter/62936. htm). Among adjustable-rate subprime mortgages, i.e. the instruments with the lowest overall creditworthiness, 25\% were delinquent or in foreclosure (Bernanke 2008). 
functioning. ${ }^{6}$ The IMF itself has suggested that, for at least some of these securities, market prices may be significantly below the expected present values of future cash flow and therefore, that market values may not provide the right signals "for making long-term value-maximizing decisions". ${ }^{7}$ At $5-15 \%$, its own estimates of loss rates for unsecuritized non-prime mortgages are much below the $30-72.5 \%$ losses in market values of mortgage-backed securities. ${ }^{8}$ To some extent therefore, the crisis must be seen as a result of market malfunctioning as well as flawed mortgage lending.

The dependence on market valuations explains the ongoing nature of the write-offs that we have observed. The fact that every few months or even every few weeks, a bank has discovered that its losses are even greater than it had previously announced is not due to a lack of forthrightness or to stupidity, but to continued changes in actual or presumed market valuations. As time has passed, markets have become ever more pessimistic. As market pessimism grew, market valuations of securities declined ever more, and the banks had to take yet more write-offs.

A few decades ago, many of these write-offs would not have been taken. If a bank had declared that it was going to hold a loan or mortgage to maturity, it would have held the loan at book value until the debtor's solvency came into doubt, without even asking what the market valuation of the security might be. The write-offs that we have seen are an artefact of the modern form of mark-to-market, or fair value accounting which has become a part of the infrastructure of risk management and of the statutory regulation of banks. Remarkably, this accounting system is used even in situations where the markets in question have broken down.

There were good reasons for switching to fair value accounting. Under the old regime, the financial straights of the savings and loans industry in the United States in the early eighties were not appropriately recognized and dealt with. As of 1980 or 1981, about two thirds of these institutions were technically insolvent. They held large amounts of mortgages that they had provided to homeowners in the sixties with maturities of some 40 years, at fixed rates of interest, typically around $6 \%$. The interest rates which these institu-

6 Thus, one reads: "The markets for many of these financial instruments continue to be illiquid. In the absence of an active market for similar instruments or other observable market data, we are required to value these instruments using models." in the Financial Report for the Fourth Quarter of 2007 that was issued by the Swiss bank UBS.

7 International Monetary Fund (2008a, 65ff).

8 For unsecuritized prime mortgages, the IMF's prediction went from a loss rate of $1.1 \%$ in April to a loss rate of $2.3 \%$ in October, from 40 billion to 80 billion dollars; for prime mortgage-backed securities, estimated losses of market values went from zero to 80 billion dollars, again $2.3 \%$ of the amount outstanding. Given the size of the stock of prime mortgages, the worsening of prospects here explains most of the difference between October and April estimates. 
tions had to pay in order to keep their depositors were well above $10 \%$. The discrepancy between the $6 \%$ that they earned on old mortgages and the much higher rates that they paid their depositors affected their annual statements of profits and losses, but was not reflected in their balance sheets. The mortgages from the sixties, which did not have any solvency problems, were carried at face value in the books even though the market value of a security that pays $6 \%$ would be much less than its face value when newly issued securities pay more than $10 \%$. Under fair value accounting, these mortgages would not have been carried at face value, the solvency problem of the S\&Ls would have been recognized, and, presumably, early corrective action would have been taken. Because the problem was not recognized and appropriately dealt with, the so-called "zombie banks" had the freedom to go out and "gamble for resurrection", i.e., to engage in highly risky lending strategies. When the risks came home to roost in the late eighties, the cleanup cost a multiple of what a cleanup in 1980 would have cost. ${ }^{9}$ The fact that, in today's crisis, some institutions have acknowledged their losses and obtained new equity capital - and others have gone under - provides us with some assurance that these institutions will not be subject to temptations like those that the savings and loans industry in the United States succumbed to in the eighties.

However, the imposition of fair value accounting for loans and mortgages enhances the scope for systemic risk, i.e., risk that has little to do with the intrinsic solvency of the debtors and a lot to do with the functioning - or malfunctioning - of the financial system. Under fair value accounting, the values at which securities are held in the banks' books depend on the prices that prevail in the market. If these prices change, the bank must adjust its books even if the price change is due to market malfunctioning and even if it has no intention of selling the security, but intends to hold it to maturity. Under currently prevailing capital adequacy requirements, this adjustment has immediate implications for the bank's continued business activities. In particular, if market prices of securities held by the bank have gone down, the bank must either recapitalize by issuing new equity or retrench its overall operations. The functioning of the banking system thus depends on how well asset markets are functioning. Impairments of the ability of markets to value assets can have a large impact on the banking system.

In this lecture, I will argue that this systemic risk explains why the subprime-mortgage crisis has turned into a worldwide financial crisis - unlike the S\&L crisis of the late eighties. I recall hearing warnings at the peak of the S\&L crisis that overall losses of US savings institutions might well amount to some 600-800 billion dollars, no less than the IMF's estimates of losses in subprime mortgage-backed securities. However, these estimates never translated into market prices, and the losses of the S\&Ls were confined to the 
savings institutions and to the deposit insurance institutions that took them over. By contrast, the critical securities are now being traded in markets, and market prices determine the day-to-day assessments of equity capital positions of institutions holding them. This difference in institutional arrangements explains why the fallout from the current crisis has been so much more severe than that of the $\mathrm{S} \& \mathrm{~L}$ crisis.

This assessment affects the lessons for regulatory reform that we should draw from the crisis. Public discussion so far has focussed on greed and recklessness of the participants. If the crisis was just the result of greed and recklessness, it would be enough for regulatory reform to focus on risk incentives and risk control, i.e., to make sure that the scope for recklessness in banking is reduced as much as possible.

I am not denying that reckless behaviour played an important role in generating the crisis. However, there is more to the crisis than just reckless behaviour. Systemic interdependence has also played an important role. Moreover, participants did not know the extent to which systemic interdependence exposed them to risks. Risk taking that, with hindsight, must be considered excessive was not just a result of recklessness, but also a result of an insufficient understanding and of insufficient information about systemic risk exposure.

Therefore, regulatory reform must also address the risks generated by such interdependence and by the lack of transparency about systemic risk exposure. The best governance and the best incentives for risk control at the level of the individual institution will not be able to forestall a crisis if the participants do not have the information they need for a proper assessment of risk exposure from systemic interdependence. Regulatory reform must either see to it that participants get this information or else, that the rules to which participants are subjected provide for a certain robustness of risk management and risk control with respect to the incompleteness of the participants' information about their exposure to systemic risk.

In the following, Section 2 will provide a general introduction to the problem of how to allocate risks that are associated with residential real estate. In this section, I will also explain why, in principle, the securitization of such risks should be regarded as a good idea, if it is done properly. Section 3 will give an overview over residential-mortgage securitization in the United States with a view to explaining what went wrong, in particular, why the moral hazard that is caused by securitization went by and large unchecked. The analysis here will distinguish between the different roles played by the different participants, mortgage originators, investment banks, rating agencies, and investors. Section 4 will explain the effects of systemic interdependence in the crisis, beginning with systemic risk that was due to some participants having highly unsound refinancing structures, and then focussing on the interplay between market malfunctioning, fair value accounting, an insufficiency 
of bank equity and the procyclical effects of prudential regulation in the crisis. The concluding remarks in Section 5 draw some conclusions for the reform of prudential regulation that now stands high on the political agenda.

\section{MATURITY MISMATCH IN REAL-ESTATE FINANCE AND THE ROLE OF SECURITIZATION}

\subsection{The Problem of Maturity Mismatch in Real-Estate Finance}

Before I turn to the actual crisis, I briefly discuss the structure of housing and real-estate finance. A fundamental fact to keep in mind is that residential housing and real estate account for an important part of the economy's aggregate wealth, in many countries more important than net financial assets. ${ }^{10}$ Another fact to keep in mind is that houses and real estate are very long-lived assets. Economic lifetimes of these assets are on the order of several decades, much longer than the time spans for which most people plan their savings and investments.

The discrepancy between the economic lifetimes of these assets and the investment horizons of most investors poses a dilemma. If housing finance were forthcoming only from investors with matching long-term horizons, there simply would not be very much of it. The ordinary saver puts funds into a savings account or similar asset where they can be withdrawn at a few months' notice, perhaps even at will. A term account may have a maturity of a few years, but this is still far short of the forty or more years of economic life of a house. Hardly anybody is willing to tie his funds up for such a long time span. Even people who plan so far ahead want to give themselves the option to change their investments at some intervening time.

If housing finance is obtained from investors with shorter horizons, someone must bear the risk that is inherent in the fact that, when the initial contract is signed, it is not clear what will happen when the financier wants to liquidate his position. This risk can be born by the homeowner. He can get a ten-year mortgage and hope that, when the mortgage comes due, it will be easy to refinance or to sell the house. The risk can also be borne by the investor. He can provide a forty-year mortgage and hope that, if he wants to liquidate this mortgage prematurely, it will be easy to find a buyer. The risk can also be borne by a financial intermediary like yesteryear's savings and loans institution in the United States, which was providing homeowners with forty-

10 For a sample of OECD countries, Slacalek (2006) gives mean ratios of housing wealth to income of 4.89 and of net financial wealth to income of 2.68 in 2002. For the United States, these ratios are given as 3.01 and 3.84 , the only case other than Belgium where net financial wealth exceeds housing wealth. The estimates of Case et al. (2005) suggest that this finding for the United States is a result of the stock market boom since the early eighties. 
year mortgages and was itself financed by savings deposits, with maturities ranging from one month to seven years.

Whatever the arrangement may be, if we observe that the risks induced by maturity mismatch are coming out badly, we should not complain that these risks have been incurred at all. If no one was willing to take these risks on, our housing stock would be limited to what can be financed by investors with suitably long horizons. We should have much less housing, and our standards of living would be much lower. The quantity and quality of housing that we have are obtained by using the funds of investors with short time horizons to finance housing and real-estate investments with very long time horizons. The risks that this mismatch creates are necessary by-products of the comfort that we enjoy.

One must, however, ask whether the mechanisms that determine the extent and the allocation of these risks are functioning well or whether these mechanisms have serious shortcomings.

Why should we think of the maturity mismatch in real-estate investment as a source of risk at all? Why can't we just say that in a well-functioning system of financial markets, finance is always forthcoming at the going price? There are two snags: Financial markets are not always well functioning, and the going price may be unaffordable.

The going price may be unaffordable: Market conditions change all the time; in particular, market rates of interest change all the time. If the risk associated with maturity mismatch is borne by the homeowner, he may find that, at the time of refinancing, the market rate of interest is so high that he is unable to service his debts at this rate. If the risk associated with maturity mismatch is borne by the investor, e.g., through a long-term fixed-rate security, he may find that, when he wants to sell the security, its price in the market is rather low. ${ }^{11}$ Because the market price of an old fixed-rate security is low if the market rate of interest for new loans is high, the debtor's refinancing risk and the investor's asset valuation risk are actually two sides of the same coin, reflecting the fact that, if market rates of interest go up, long-lived assets with given returns become relatively less attractive.

Financial markets are not always well functioning: We often think of financial markets as being so well organized that one can always find a trading partner, buying or selling, at "the going price" plus or minus a very small margin. While this may be true for the markets for government bonds or certain large stocks, many financial markets do not have this property.

11 By a precisely symmetric consideration, investors holding short-term assets may find that, if they want to reinvest their funds after all, the rate of interest at which they can do so is rather low (and long-term assets are expensive to buy). A systematic account of the different risks associated with changes in market rates of interest is given in Hellwig (1994a). 
Information and incentive problems make trading partners wary lest the offer they are considering should be harmful to them.

Akerlof (1970)'s famous model of the used-car market is paradigmatic for the problem. In Akerlof's analysis, people who know their cars to be of good quality are less willing to sell them at "the going price" than people who know their cars to be "lemons", i.e., poorly made. ${ }^{2}$ At any given price, potential buyers appreciate that the cars that are being offered at this price represent a negative or "adverse" selection. In the absence of a mechanism for quality certification, the average price of a used car that is traded in the market must therefore involve a discount relative to the price that would be paid for a car whose quality is known to correspond to the average for that make and year. Trading volume is therefore less than it would be under complete information. Nor does the problem stop there: The discount itself is likely to discourage further car owners from offering their cars for sale. The adverse-selection problem is thereby exacerbated. This may require a further discount in the price, which in turn can exacerbate the adverse-selection problem. In extreme cases, the market may break down completely, i.e., no car may be traded even though, in terms of the underlying needs and preferences, it would be mutually beneficial to have trades that reallocate cars from people who need them less to people who need them more.

Like the potential buyer of a used car, the buyer of a financial security must worry about the quality of what he buys. If he suspects that the security is being offered because the seller knows that the security has a problem, he will not be willing to buy it unless he is given a large discount. Because the potential sellers' reactions to the discounts depress quality even more, trading volume can be reduced to a bare minimum; as in the used-car market, there may even be a complete market breakdown. Thus, an investor who has provided long-term finance to a homeowner may find it difficult to sell his claim to another investor when he needs the money - the other investor is afraid of his knowing something about the borrower's solvency. Alternatively, a homeowner who has taken out a mortgage of limited maturity may find it difficult to refinance because investors have doubts about his ability to service his debt.

The history of real-estate finance provides ample material to illustrate the risks associated with maturity mismatch in real-estate finance. In many countries, for a very long time, real-estate finance was provided through fixedrate mortgages. As mentioned above, in the United States before 1980, these mortgages were provided by savings and loans institutions that were themselves financed by short-term deposits at regulated rates of interest, of 3-5\%.

12 In Germany, the term would be, „Montagsauto“, a car that was put together on a Monday when workers were still dreaming of their weekend exploits, rather than watching what they were doing. 
However, in the late seventies and early eighties, when nominal rates of interest were high, these institutions found that their depositors were leaving them for money market funds that were offering interest rates above $10 \%$. The problem of illiquidity which this posed was solved by a deregulation of deposit rates. However, with deposit rates shooting up to the level that was needed to compete with money market funds, the profitability of these institutions was squeezed by the discrepancy between deposit rates and mortgage rates that had been contracted long ago. Indeed, because of this squeeze, a substantial portion of the United States savings and loans industry was technically insolvent at the time of deregulation. ${ }^{13}$

Given this experience, market participants went looking for new arrangements. In the early eighties, real estate finance moved from fixed-rate to adjustable-rate mortgages. The interest rate risk was thus shifted to the borrowing homeowners, in many European countries as well as the United States. However, when market rates of interest rose again in the late eighties, mortgage lenders found that many of their borrowers were unable or unwilling to fulfil their obligations at the newly adjusted rates; in technical language: the interest rate risk that the lenders thought they had gotten rid of had merely been transformed into a counterparty credit risk. ${ }^{14}$ They also were unpleasantly surprised to find that, when they tried to repossess the properties, the proceeds were low because the high market rates of interest were depressing property values. High interest rates inducing high default rates and depressing property values were a key ingredient in the banking crises that hit many European countries and Japan as well as the United States in the late eighties and the early nineties. ${ }^{15}$

\subsection{The Role of Securitization}

Another approach to the problem of risk allocation in real-estate finance was provided by securitization. This financial innovation was developed in the eighties in the United States. In the nineties, reliance on securitization greatly expanded so that, by the end of the decade, it accounted for the bulk of real-estate finance. Under securitization, sometimes referred to as the originate-and-distribute model of mortgage finance, the originating institution, traditionally a bank or a savings institution, will transfer mortgage titles to a special-purpose vehicle, a specialized institution that puts a large set of

13 See Kane (1985, 1989), Benston et al. (1991).

14 The shift to adjustable-rate instruments in the first half of the eighties is deemed to explain at least part of the increase in credit risk in this decade; see Hendershott and Shilling (1991), Schwartz and Torous (1991).

15 In the UK, the brunt of the crisis was actually borne by the insurance industry that had provided the building societies with credit insurance on the basis of the idea that default on a loan is an insurable event! 
mortgages into a package and that refinances itself by issuing "mortgagebacked securities", i.e. securities whose claims are defined with reference to the returns that are earned by the package of mortgages. The risks of mortgage finance are thus transferred from the originating institution to the special purpose vehicle and to the holders of the mortgage-backed securities.

The mortgage-backed securities themselves are not just defined as percentages of the mortgage portfolio, but are structured into tranches, which are ranked according to their priorities. In the simplest case, there are three such tranches. The first tranche, usually referred to as the senior tranche, has a contractually specified claim on the mortgage portfolio. If the return on the mortgage portfolio falls short of this claim, the holders of the senior tranche get the entire return and share it according to the shares of the senior tranche that they hold. If the return on the mortgage portfolio exceeds the claim of the senior tranche, the claim of the senior tranche is paid off. The second tranche, usually referred to as the mezzanine tranche, also has a contractually specified claim on the mortgage portfolio. However, this claim is subordinated to the claim of the senior tranche. If the return on the mortgage portfolio falls short of the claim of the senior tranche, the holders of the mezzanine tranche get nothing. If the return on the mortgage portfolio lies between the claim of the senior tranche and the sum of the claims of the senior and mezzanine tranches, the holders of the mezzanine tranche get the entire excess of the return over the claim of the senior tranche and share it according to the shares of the mezzanine tranche that they holds. If the return on the mortgage portfolio exceeds the sum of the claims of the senior and mezzanine tranches, the claim of the mezzanine tranche is also paid off. The holders of the final tranche, usually referred to as the equity tranche, receive what is left after the senior and mezzanine tranches have been served. If the return on the mortgage portfolio falls short of the claims of the senior and mezzanine tranches, the holders of the equity tranche do not receive anything. Otherwise they receive the excess of the return on the portfolio over the claims of the senior and mezzanine tranches.

Does this arrangement make economic sense? Before I discuss its flaws and before I explain how these flaws contributed to the current crisis, I want to stress that the system of real-estate finance based on mortgage-backed securities has some eminently reasonable features. First, this system permits the originating institution to divest itself of the interest rate risk that is associated with real-estate finance. The experience of the US savings \& loans industry has shown that depository institutions are not well able to bear this risk. The experience with adjustable-rate instruments has also shown that debtors are not well able to bear this risk and that the attempt to burden them with it may merely transform the interest rate risk into a counterparty credit risk. Securitization shifts this risk to a third party. 
In principle, shifting this risk away from the originating institution and its debtor makes sense because there are other market participants who are better able to bear this risk. Some market participants actually have long investment horizons and therefore do not consider the interest risk of real-estate finance to be a risk at all. Thus, an insurance company or a pension fund has liabilities with maturities of twenty years or more, not too far removed from the economic life of a real-estate investment or the maturity of a mortgage instrument. If such an institution invests in a long-term fixed-rate instrument, i.e., a mortgage or a mortgage-backed security, the question of how the market values this instrument at intervening dates is irrelevant because there is no point in liquidating this investment anyway and the institution's ability to fulfil its obligation to its own financiers depends on the returns from the security rather than the market's assessment. Indeed, for an insurance company or pension fund, a fall in the value of long-term securities that is induced by an increase in interest rates tends to be unproblematic. The very increase in interest rates provides the institution with scope to earn higher returns on new investments and thereby to better fulfil its obligations to its insurance and pension customers. ${ }^{16}$

Even if one cannot a priori distinguish between short-term and long-term investors, the securitization of long-term investments can still make economic sense. Thus, in the context of a model in which investors do not know beforehand when they will want to consume, Hellwig (1994a) shows that it is optimal to have an arrangement where people stipulate the amounts of short-term and long-term assets that they want to hold, with the proviso that, if they find that they want to consume early, they should bear the interest-induced valuation risk of long-term investments, and, if they want to consume late, they should bear the interest-induced reinvestment risk of short-term investments. All risks that are associated with changes in interest rates should thus be shifted to final investors. Securitization provides one way to achieve this.

The marketing of these securities also provides room for improvements in the worldwide risk allocation. It is fashionable these days to deride European bankers who invested in US mortgage-backed securities without understanding anything about real-estate markets in the United States. However, before we adjust our regulations to prohibit such adventures in the future, we should recall that experiences with real estate finance in domestic markets have not been that propitious either. A paradigmatic example is again provided by the

16 For such institutions, the relevant form of interest rate risk is actually the risk, considered in fn. 11, that, if it invests short-term, the rate of return on reinvestments after the first investments have matured may be too low relative to their obligations to insurance customers and pension savers. Thus, in the second half of the nineties, life insurers in Germany were squeezed by the difference between the rates of return that they had promised their customers in the early nineties and the rates of return that they could earn in the market after the rate decline of the mid-nineties. 
United States savings and loans industry. Under the old regime, before deregulation, some states had rules requiring their savings banks to invest in mortgages for properties in the very state. Such a rule was a major cause of the S\&L crisis in Texas in 1986, which preceded the general S\&L crisis by more than a year: Following the collapse of oil prices in 1985, the Texan economy went into a recession, and real-estate prices in Texas fell. Savings and loans institutions in this state were hit by this Texas-specific risk because the regulation in question did not permit them to diversify their risks across states. A lack of geographic diversification of real-estate finance also played a role in the various banking crises of the late eighties and early nineties, in particular the crises in the Scandinavian countries and in Switzerland. ${ }^{17}$ The experience of German banks with real-estate finance in the Neue Länder, the former GDR, in the early nineties was similarly unpropitious. ${ }^{18}$

As a matter of principle, it makes economic sense for institutions in Europe or Japan to be holding securities related to real-estate investments in the United States and other countries as well as their own. By holding securities related to real-estate investments in different countries, they obtain a better diversification of risks in their portfolios. To be sure, such investments can be fraught with information and incentive problems. However, such problems arise even if one invests in one's own country, sometimes even more poignantly than if one invests abroad. ${ }^{19}$

The formation of packages and tranches also makes economic sense; it can serve to defuse the very information and incentive problems that would otherwise prevent the sharing of risks between investors. By comparison to a single mortgage, an asset that is backed by a package of mortgages benefits from diversification of default risks across the different mortgages in the package. Packaging also provides for standardization. A package is more likely to be

17 For Sweden and Finland, see Berglöf and Sjögren (1998), Englund (1999) and Takala and Virén (1995), for Switzerland, Staub (1998b). The Swiss case is particularly interesting: Whereas many cantonal and regional banks whose fields of operations were limited to Switzerland, or even to the canton or region where they were located, became insolvent as a result of the crisis in real-estate markets and real-estate lending, the big banks were able to compensate their losses in these activities by profits in internal derivatives markets.

18 In this context, it is worth mentioning that, in the breakdown of the German mortgage lender Hypo Real Estate in October 2008, a major role seems to have been played by bad loans on real estate in the Neue Länder from the early nineties, which had been taken over from HVB, the institution that had created Hypo Real Estate before it was itself taken over by Unicredito. (Another factor in the breakdown was the excessive reliance of a major subsidiary on short-term refinancing; the role of excessive maturity transformation in the crisis will be discussed in Section 4 below.)

19 For evidence on this point, see the accounts of the Scandinavian crises in Berglöf and Sjögren (1998), Englund (1999) and Takala and Virén (1995). In Germany, Deutsche Bank's providing mortgage finance for a building with a purported $5000 \mathrm{~m}^{2}$ of office space when the actual area was $2000 \mathrm{~m}^{2}$ has become legendary. 
considered as a part of a standardized class of assets than any one specific mortgage would be. Such standardization can reduce the kind of "lemons" problem that I discussed above. Whereas the attempt to sell a single mortgage or an asset backed by a single mortgage would raise the suspicion that the seller knows this particular mortgage to be having problems, a package that involves a mix of such securities is less likely to raise such suspicions, especially, if a rating agency confirms that the mix conforms to some sort of average of securities of this kind. Thus, until last year, market participants thought that they knew what an AAA-rated senior-tranche mortgage-backed security was and were not afraid that someone offering this security for sale was doing so because he had inside information on default prospects of the mortgage borrowers. Standardization by packaging provides for marketability in a way that would hardly be available for individual securities. ${ }^{20}$

Tranching should be understood as a way of reducing moral hazard in origination. Past experience suggests that the distribution of losses in lending is highly skewed. On the basis of this experience, losses on a diversified portfolio of mortgages could be expected to be below $10 \%$ with a probability close to one; losses above $10 \%$ could be deemed to be quite unlikely. Splitting the claims to the portfolio returns into tranches as described above would thus leave the holder of the equity tranche holding practically all of the risk. If the claims of senior and mezzanine tranches together amount to no more than $95 \%$ of the aggregate of claims on mortgage borrowers, the holders of senior and mezzanine tranches would be almost immune from default risks attached to the underlying securities. These risks would mainly affect the equity tranche. If the equity tranche was held by the originating institution, this institution would in fact have the proper incentives to investigate the creditworthiness of the borrowers before lending them money and originating the mortgage; after all, the risks of making a mistake in this decision would mainly hit the originating institution itself. $^{21}$

In theory, therefore, the system of securitization of real-estate finance through mortgage-backed securities seems like a good way to shift a substantial part of the risks that are due to the mismatch between the economic lifetimes of real-estate investments and the horizons of investors away from the originating institutions and their debtors without impairing the incentives of originating institutions to be careful about the real-estate investments that they financed. The system would thus seem to provide a substantial improvement in the allocation of risks in the worldwide financial system.

What then went wrong? In several important respects, the practice was different from the theory: First, moral hazard in origination was not

20 Duffie (2007). A general treatment of the role of standardization is provided by Gale (1992).

21 For a more detailed account of the argument, see Franke and Krahnen (2006). 
eliminated, but was actually enhanced by several developments. Second, many of the mortgage-backed securities did not end up in the portfolios of insurance companies or pension funds, but in the portfolios of highly levered institutions that engaged in substantial maturity transformation and were in constant need of refinancing. Third, the markets for refinancing these highly leveraged institutions broke down in the crisis.

I now turn to these problems and discuss the causes of the current crisis. The following section discusses the problem of moral hazard in origination and analyses the flaws in mortgage securitization that underlay the current crisis. Subsequently, Section 4 discusses the systemic repercussions that turned the subprime-mortgage crisis into a world financial crisis.

\section{MORAL HAZARD IN MORTGAGE SECURITIZATION: THE ORIGINS OF THE CRISIS}

\subsection{Moral Hazard in Origination}

At a conference on financial contracting in April 2007, one presentation began with a picture of a building with the advertisement "For Sale! Price: 130.000 \$, Cash Back: 20.000\$". At first sight, this advertisement poses a puzzle. Why should a seller ask for $130.000 \$$ and at the same time promise to repay the buyer $20.000 \$$ ? Why not just set a price of $110.000 \$$ ? The puzzle disappears if one considers that the sales price of $130.000 \$$ would appear in the mortgage loan application to the bank. If the bank accepted this number at face value, it would provide a larger loan than it would if it knew that the effective price is only $110.000 \$$. By reporting an inflated sales price, the buyer and seller together were attempting to defraud the bank.

The presenter went on to provide empirical evidence that the incidence of such fraud, also the incidence of collusion between property appraisers and borrowers, was significantly higher when the originating lender was planning to put the mortgage into a package of mortgages that would be sold for securitization than when he was planning to hold the mortgage himself. ${ }^{22}$ Such findings indicate that there has been significant moral hazard in the origination of mortgages that were due to be securitized. Presumably, lenders who were planning to hold the mortgages themselves had greater incentives to fight fraud on the side of borrowers. Indeed, a lender who plans to resell the entire mortgage may not worry about the debtor's ability to pay at all and merely aim at increasing volume so as to earn more fees by originating and reselling mortgages.

Moral hazard is, in principle, present in any financial transaction. A person who works with his or her own money has greater incentives to take care 
of what happens with the investment than a person who works with somebody else's money. ${ }^{23}$ In the case of a financial institution, this moral hazard is particularly bothersome because the institution's assets are very diverse and highly fungible. This makes it difficult for outside investors to monitor the institution's activities and to take corrective actions if they see something going wrong. ${ }^{24}$ In the theory of financial institutions, therefore, the paradigmatic model of viable financial intermediation, due to Diamond (1984), postulates an intermediary holding a fully diversified portfolio of assets, with outside finance taking entirely the form of debt, with claims that are independent of the returns which the intermediary earns on his portfolio: If the claims on the financial intermediary are independent of returns on the intermediary's assets and if diversification ensures that the probability of default is zero, any benefits of taking greater effort in managing assets, e.g., more thorough monitoring of loans clients, accrue entirely to the intermediary. The problem of moral hazard in relations between the intermediary and his financiers is thereby eliminated altogether.

Whereas the Diamond model relies on the virtues of debt finance in dealing with moral hazard when there is no default risk, we also know that, if there is a default risk, debt finance provides the borrower with an incentive to take excessive risks, i.e., risks that would not be incurred if his investment strategy was determined by mutual agreement with his financiers. The incentive arises from the consideration that, whereas extra returns in the event of success accrue to the debtor, an increase in the probability of default harms the creditors, according to the principle "heads, I win - tails, my creditors lose". 25

Given the theoretical analysis, one always had to suspect that the securitization of credit risks would be a source of moral hazard that could endanger the viability of the system. ${ }^{26}$ The system of splitting the claims to a portfolio of assets into tranches can actually be seen as a response to this concern. We can think of the senior and mezzanine tranches as senior and junior debt. If the originating institution were holding the equity tranche and if, because of packaging and diversification, the probability of default, i.e., the proba-

\section{Jensen and Meckling (1976).}

24 Diamond (1984), Myers and Rajan (1998).

25 Jensen and Meckling (1976), Stiglitz and Weiss (1981).

26 See Hellwig (1998a,b). Based on Diamond (1984), already Hellwig (1994a) had suggested that a securitization of the interest rate risk inherent in long-term assets would have to be engineered in such a way that asset-specific return risks would stay with the intermediary since otherwise the intermediary would have too little incentive to take care in selecting and monitoring loan clients. Hakenes and Schnabel (2008) provide a formal model of the moral hazard in origination that is generated by credit risk transfer. Because the counterparties are aware of the moral hazard and prices are set accordingly, in their model, the overall welfare effects of credit risk transfers are positive despite the mora hazard that they generate. 
bility that portfolio returns fall short of the sum of senior and mezzanine claims, were (close to) zero, we would (almost) be in the world of the Diamond model where moral hazard in banking is negligible. Why then did this system fail?

The answer to this question is straightforward: Both "ifs" in the preceding statement were not satisfied. Originating institutions did not, in general, hold the equity tranches of the portfolios that they generated; indeed, as time went on, ever greater portions of equity tranches were sold to outside investors. ${ }^{27}$ Moreover, default probabilities for senior and mezzanine tranches were significant because, by contrast to the Diamond model, packaging did not provide for sufficient diversification of returns on the assets in mortgage-backed portfolios.

Except when default risk on the individual mortgage is altogether eliminated, the returns on different mortgages are necessarily correlated. The returns that lenders earn in default depend on property values. Property values depend on common as well as asset-specific factors. Whereas asset-specific factors, such as geographic location or the characteristics of the neighbourhood, are likely to be independent and can therefore be diversified away, common factors, such as the susceptibility to changes in interest rates or to changes in macroeconomic conditions, cannot be diversified away. Because they affect all real-estate properties at the same time, they necessarily introduce a correlation into the default risks that are associated with different mortgage securities. For example, an interest rate increase that depresses property values enhances the prospect that any borrower's equity in his property might become negative and that he might prefer to walk away rather than to stay and continue servicing the loan. Because of these correlations, diversification in the portfolios underlying the mortgage-backed securities was less effective, and default risks for senior and mezzanine tranches were more significant than had been anticipated.

\subsection{Mortgage Lending in the Years Before the Crisis}

For a long time, moral hazard in origination seems to have been reasonably contained. The creation of mortgage-backed securities was almost entirely in the hands of Fannie Mae and Freddie Mac, as the Federal National Mortgage Association and the Federal Home Loan Mortgage Corporation are commonly called. These government-sponsored enterprises ${ }^{28}$ provided the buyers of mortgage-backed securities with a guarantee for the promised debt

27 Duffie (2007), Dodd (2007).

28 The term government-sponsored enterprises refers to the fact that, although these institutions have been privatized in the late sixties, they are deemed to serve a public purpose and therefore enjoy certain tax privileges, as well as access to the US Treasury for liquidity needs. 
service; at the same time, they imposed certain minimum standards on mortgage debtors, namely, high credit scores reflecting large down payments, low ratios of debt service to documented available income, and reliable credit histories of mortgage borrowers. For mortgages that met these standards, socalled "prime mortgages", delinquency rates and default rates were - and still are - very low. ${ }^{29}$

Fannie Mae and Freddie Mac had in fact played a key role in the development of the markets for mortgage-backed securities. When they began to buy mortgages, to package them, and to sell the mortgage-backed securities in the open market, the mortgage-backed securities were acceptable to investors because Fannie Mae and Freddie Mac also provided guarantees for the promised payments from these securities. The origins of Fannie Mae and Freddie Mac as government institutions led many investors to believe that, even though these institutions had been privatized, their guarantees had some kind of backing from the government ${ }^{30}$ and could therefore be deemed to be reliable. $^{31}$

However, in the years since 2000, Fannie Mae and Freddie Mac have been challenged by competition from other financial institutions, in particular, private investment banks, which did not guarantee their issues of mortgagebacked securities in the same way as Fannie Mae and Freddie Mac. The share of the government-sponsored enterprises in the issuance of mortgage-backed securities went from $76 \%$ in 2003 to $43 \%$ in $2006 .{ }^{32}$ At the same time, there was a relative decline in prime mortgage lending and a significant increase in subprime mortgage lending, i.e., in the issuance of mortgages that did not

29 The difficulties that Fannie Mae and Freddie Mac have had in the crisis had more to do with their being pressured by the political system to provide support for subprime mortgagebacked securities in 2007 than with problems in the prime mortgages that had been their main business. However, one suspects that the expansion in prime mortgage lending between 1995 and 2003 may have been accompanied by a decline in borrower quality. This would be the analogue for prime mortgages of findings of Demyanyk and Van Hemert (2008) showing that, since 2001, in subprime mortgage lending, there have been declines in borrower quality that go beyond the effects of changes in observables such as down payment rates, credit scores and the like.

30 Since the privatization of these institutions in the late sixties, this belief would not have had any basis in the law. Even so, the developments since July 2008 have shown that this belief was justified. The position of Fannie Mae and Freddie Mac in the system of housing finance in the United States is too important for the government to look aside when these institutions run into trouble.

31 Thus, at the time when the system of mortgage-backed securities was developed, the neglect of moral hazard induced by securitization was at least partly due to a reliance of market participants on government guarantees.

32 See Dodd (2007). The challenge in the market was preceded by political discussions about these institutions' roles including accusations by the US Government of errors in dealing with new accounting rules for derivatives. These discussions induced the government-sponsored enterprises to retrench their activities in the market. 
meet the standards of the government-sponsored enterprises. The share of subprime mortgages rose from around 9\% of new mortgages in the early 2000's to above $40 \%$ in $2006 .{ }^{33}$ By the end of 2006, subprime mortgages accounted for some $14 \%$ of the total stock of outstanding securitized mortgages $(7 \%$ in 2001)..$^{34}$

These changes have caused the quality of mortgages to go down. According to the International Monetary Fund (2007), the share of the stock of securitized mortgages in which the loan accounted for more than $90 \%$ of the property value went from about $5 \%$ in 2001 to $14 \%$ in 2006 ; the share of securitized mortgages with limited documentation of income went from $7 \%$ in 2001 to $18 \%$ in 2006 . These changes in mortgage quality are linked to the rise of nonprime lending: Average down payments in near prime mortgages, the so-called Alt-A mortgages, and in subprime mortgages were $12 \%$ and $6 \%$, respectively, substantially below down payments in prime mortgages; in many instances, there was no down payment at all. In 2006, there was less than full documentation of income in $81 \%$ of Alt-A and $50 \%$ of subprime mortgages, as opposed to $36 \%$ of prime mortgages. ${ }^{35}$

These years also saw the resurrection of adjustable-rate mortgages. Their share of the stock of outstanding mortgages went from $6 \%$ in 2001 to $26 \%$ in $2006 .{ }^{36}$ In 2006 indeed, 92\% of newly issued subprime mortgages, $68 \%$ of newly issued Alt-A mortgages, and $23 \%$ of newly issued prime mortgages had adjustable rates. ${ }^{37}$ The lesson of the eighties, that adjustable rates cause credit risk to be higher, seems to have been lost - perhaps forgotten, perhaps also neglected because, after all, the credit risk would affect the holders of mortgage-backed securities rather than the originators of the mortgages.

33 Chomsisengphet and Pennington-Cross (2006), DiMartino and Duca (2007), International Monetary Fund (2007).

34 DiMartino and Duca (2007), International Monetary Fund (2007). These two sources differ on the importance of Alt-A (near prime) mortgages. Whereas DiMartino and Duca assess the stocks of Alt-A mortages and of prime mortgages at $6 \%$ and $80 \%$ of the total, the IMF puts Alt-A mortgages at $12 \%$ and prime mortgages at $74 \%$ of the total, $65 \%$ as prime mortgages held by government-sponsored enterprises and $9 \%$ held by non-agency private institutions. However, whereas the IMF's numbers refer to securitization-related mortgages, DiMartino and Duca seem to be referring to all mortgages. In any case, given the problems of drawing precise lines between different classes and given the question of data reliability, these numbers should be taken with a grain of salt, indications of orders of magnitude, rather than precise measures.

35 DiMartino and Duca (2007). The fact that $36 \%$ of prime mortgages involved less than full documentation of income indicates that, even in this part of the market, lending standards had declined.

36 International Monetary Fund (2007).

37 DiMartino and Duca (2007). The International Monetary Fund (2007) gives the shares of adjustable-rate mortgages as $85 \%$ for subprime mortgages, $55-60 \%$ of Alt-A and prime mortgages and less than 20\% for mortgages securitized by Fannie Mae and Freddie Mac. 
The changes in mortgage quality are reflected in their performance, or mal-performance, in the crisis. Since 2006, delinquency rates and foreclosure rates have steadily gone up. According to the Mortgage Bankers Association, at $6.35 \%$, the delinquency rate, i.e., the share of mortgages with payments outstanding 60 days or more, in the first quarter of 2008 was the highest (on a seasonally adjusted basis) since they began collecting the data in 1979. At $2.47 \%$, the foreclosure rate, i.e., the share of outstanding mortgages in foreclosure proceedings has more than doubled since the end of 2006. As a function of the number of months since the conclusion of the mortgage contract, delinquency rates on mortgages issued in 2006 have been rising more steeply and have been higher than delinquency rates in any previous year in this decade; delinquency rates on mortgages issued in 2007 are even worse. ${ }^{38}$

As one would expect, the problems are concentrated in the subprime segment of the market: Delinquency rates in this segment are on the order of $25 \%$, as opposed to $10-12 \%$ for Alt-A mortgages and $1-2 \%$ for prime mortgages. ${ }^{39}$ Adjustable-rate subprime mortgages, with a share of $7 \%$ of the total outstanding mortgage stock, account for about $39 \%$ of foreclosures. By contrast, fixed-rate prime mortgages, with a share of $65 \%$ of the total outstanding mortgage stock, account for only $18 \%$ of foreclosures. ${ }^{40}$ The doubling of the foreclosure rate over the past year thus seems to have been largely a consequence of the previous expansion of subprime lending.

Striking though they are, in and of themselves, these numbers do not necessarily prove that the system went astray. They prove that there was a relaxation of credit standards and an expansion of lending to riskier borrowers, and theory makes us speculate that this was due to moral hazard in origination. However, an advocate of the expansion of subprime lending might argue that previous credit standards were too restrictive, denying the benefits of home ownership to an unnecessarily large part of the population. The development and expansion of subprime lending did serve to expand the share of Americans living in their own homes from around $63.4 \%$ to just below $69.2 \%{ }^{41}$ Among the new home owners, many are not subject to foreclosure proceedings and may still be happy about their moves.

An advocate of the expansion of subprime lending might also argue that there is nothing intrinsically bad about higher credit risks, provided the creditors are aware of these risks and price them properly. The development in subprime lending was said to have been made possible by improvements

38 International Monetary Fund (2008a), Demyanyk and Van Hemert (2008).

39 International Monetary Fund (2008a).

40 For fixed-rate subprime mortgages, the corresponding shares are $6 \%$ of the total and $11 \%$ of foreclosures, for adjustable-rate prime mortgages, $15 \%$ of the total and $23 \%$ of foreclosures. All numbers are taken from the Mortgage Bankers Association, http://www.mortgagebankers. org/NewsandMedia/PressCenter/62936.htm.

41 DiMartino and Duca (2007). 
in credit scoring techniques, transferring such techniques from automobile loans to home loans. ${ }^{42}$ Interest rates on subprime mortgages were said to properly reflect the higher credit risks, providing for risk premia where risks were higher. ${ }^{43}$ Couldn't it be the case that the government-sponsored entities Fannie Mae and Freddie Mac had simply not been sufficiently innovative?

I do not actually share this view. I merely present it in order to show how difficult it is to assess a development that has gone astray. Once things have gone wrong, hindsight suggests that these loans should not have been made. However, hindsight is not a useful guide. The question must be whether we have evidence that, beforehand, it was, or should have been, clear that these loans should not be made.

At this point, I return to the example by which I introduced the discussion of moral hazard in origination. Telling the bank that the sales price is $130.000 \$$ when, effectively, it is only $110.000 \$$ is an instance of fraud. A report of the United States Financial Crimes Enforcement-Network (2006) in fact shows that over the past decade, mortgage fraud has increased dramatically, going from 1318 reported instances in 1996 to 25989 reported instances in 2005, an almost twentyfold increase. Annual rates of increase were around $30 \%$ from 1996 to 2002 and then jumped to $77 \%$ in 2003, 93\% in 2004 and $41 \%$ in 2005. It is hardly a coincidence that the most dramatic increases occurred in the very years when the system of mortgage finance and mortgage securitization underwent the structural changes that I have described. Greater allowances for risk have gone along with reduced attention to fraud. The econometric analysis of Ben-David (2006/2008) provides evidence of the link between the incidence of fraud and securitization.

In this context, it is worth noting that, even though the increases in delinquencies and foreclosures are concentrated in adjustable-rate subprime mortgages, they do not seem to be triggered by the resetting of interest rates. The IMF points out that foreclosures seem to take place well ahead of the resetting of interest rates and suggests that "the deterioration thus far has been a function of fraud, speculation, over-extension of borrowers, and the effects of weak underwriting standards". 44

An econometric study by Demyanyk and Van Hemert (2008) of delinquencies in a large sample of mortgage loans shows that the decline in the quality of subprime mortgages actually transcends anything that we can attribute to observable characteristics such as adjustable rates, low credit scores, low down payments, or high ratios of debt service to income. For subprime mortgages of different years since 2001, the study finds that, even after everything else is taken into account, there is a positive effect of vintage on delinquency 
rates 12 months after origination of the mortgage contract. The probability of such a delinquency on a mortgage issued in 2006 is higher than the corresponding probability for a mortgage issued in 2005 , the latter again is higher than the corresponding probability for a mortgage issued in 2004, and so on. Moreover, the difference is not fully explained by the decline in the quality of characteristics such as credit scores, down payments, etc. In full accord with the IMF's reference to "weak underwriting standards", there seems to have been a decline in the quality of subprime mortgages even beyond the worsening of their observable characteristics. The regression results indicate that this "unexplained" quality decline has been going on since 2001. However, before 2006 , the effects of this quality decline on delinquency rates were outweighed by the effects of increases in property prices, which provided mortgage borrowers with additional equity, increasing their stakes in their properties and also providing a basis for taking out additional loans in order to service their outstanding debts. ${ }^{45}$

The study of Demyanyk and Van Hemert also shows that differential risk premia for subprime mortgages went down at the very same time as risks in these mortgages went up. In the sample they studied, the difference between the average interest rate on fixed-rate subprime mortgages and the average interest rate on fixed-rate prime mortgages was well above 300 basis points (3 percentage points) in 2001. Following a steady decline from 2001 to 2004, this difference reached 100 basis points in that year, and then jumped back up to around 150 basis points where it stayed until the end of 2005; in 2006, it rose towards 200 basis points, still significantly less than where it had been in 2001 .

This behaviour of risk premia on subprime mortgages is something of an anomaly. The decline from 2001 to 2004 has no parallel in other parts of the financial system, e.g., in the behaviour of risk premia on bonds with low credit ratings. Therefore it cannot be ascribed to a general increase in investors' willingness to incur risks. In the absence of an increase in the willingness to bear risk, risk premia on subprime mortgages should have gone up, rather than down, so as to reflect the decreasing quality of these titles. Given that the opposite happened, one must have doubts about the notion that interest rates on subprime mortgages were appropriately set to reflect the higher credit risks on these securities.

45 Demyanyk and Van Hemert (2008) also show that the assessment is unchanged if foreclosure rates, rather than delinquency rates, are considered. Hakenes and Schnabel (2008) attribute such quality deterioration to intensifying competition by originators, Rona-Tas and Hiß (2008) to the effects of increased gaming by mortgage borrowers (and brokers?) on the reliability of credit scores. 


\subsection{Negligence in Securitization: Blindness to Risk in the Competition for Turf}

The fact that risk premia on subprime mortgages went down even as risks in subprime mortgages went up indicates that the expansion of subprime mortgage lending was driven by the supply of funds rather than the demand for funds in these markets. Increased mortgage lending was driven by investors seeking an outlet for their money. Mortgage originators, as well as home purchasers and home owners mostly seem to have been responding to the opportunities that this offered. ${ }^{46}$ The question is therefore why investors were so keen to put their funds into subprime mortgage finance that they allowed risk premia to go down even as risk in subprime lending went up.

Some of the answer to this question is provided by a report that the Swiss bank UBS sent to its shareholders in April. ${ }^{47}$ With losses exceeding 30 billion US dollars, UBS has been particularly hard hit by the crisis. They had played a very active role in the creation of MBS CDOs, collateralized debt obligations whose collaterals consisted of packages of subprime mortgage-backed securities, and they had also acquired such MBS CDOs on their own account. In the past, they had prided themselves on having one of the most competent systems of risk management and risk control in the world. The report tries to assess where and why their system failed. Its main findings can be summarized as follows:

- There was an excessive emphasis on revenue and growth, with insufficient attention given to risk and risk capacity. The focus on growth was motivated by a concern that UBS was falling behind leading competitors in investment banking. The "competitive gap" was deemed to be particularly large in the area of fixed-income securities. Activities in asset-backed securities, mortgage-backed securities, and adjustable-rate mortgages "were identified as significant revenue growth opportunities".

- There never was any "holistic" or comprehensive assessment of this strategy and of the risks that it involved. Risk management and risk control put excessive confidence in credit ratings provided by rating agencies and failed to provide their own analysis of credit risks in the underlying securities. They also put excessive confidence in received quantitative methods of analysis, stress tests and estimates of value at risk using statistical models based on time series data of the past five years. At the same time, they neglected possible correlations between the risk involved in "warehousing" securities in the process of securitization and the risk inherent in the securities that were held on the bank's own account. They also paid insufficient attention to systemic risks such as failures of counterparties to 
hedging arrangements or a disappearance of liquidity from relevant markets. Finally, they failed to take account of new information, e.g., about rising delinquency rates, or of the role of correlations induced by the common dependence of the performance of residential mortgage-backed securities on the overall development of the US housing market.

- Because of a reorganization that had taken place in 2005, the subsidiary in charge, UBS Investment Banking, was suffering from a lack of risk management expertise in the area of fixed-income securities. Risk incentives were also inappropriate: If additional revenue was earned for the bank by investing in subprime mortgage-backed securities rather than a government bond or by securitizing portfolios consisting of mezzanine claims, rather than senior claims, on a mortgage portfolio, the manager would earn a reward for the additional revenue without any deduction for additional risks. If a more effective and more expensive hedging arrangement to reduce risks was replaced by a less effective and cheaper one, the manager would earn a reward for saving on costs without any deduction for the lower quality of the hedge.

- Control from above was ineffective. Because of piecemeal reporting to Senior Group Management and because of fragmented control structures, there was no forum where the investment bank's strategy of expanding activities in subprime mortgage-backed securities would be discussed in a comprehensive manner and, possibly, challenged. The problem was compounded by a lack of established operational principles for the management and control of risks at the level of the overall balance sheet of the institution. For a long time, UBS Investment Banking successfully resisted the imposition of such principles and of hard limits on its holdings of illiquid assets and on its overall balance sheet. They only accepted such limits in July 2007, when the severity of the crisis could no longer be overlooked. Until then, their engagements in mortgage-backed securities had kept growing at a high rate.

Competition for market shares with insufficient regard for risks and costs is a well known cause of financial difficulties. In the financial sector, such competition has often been observed in banking systems following market liberalization. Relevant examples are provided by the United Kingdom, where the lifting of credit controls in 1971 was followed by such competition leading to the Secondary Banking Crisis in $1973,{ }^{48}$ and Sweden, where deregulation in the mid-eighties was followed by such competition leading to the banking crisis of $1992 .{ }^{49}$ In such markets, participants tend to be driven by a notion that the early phase of development determines long-run turfs, and that, to be "with it", one has to succeed in this competition for turf. 
The UBS Report to Shareholders suggests that something similar happened in the markets for mortgage securitizations since 2003. As the government-sponsored enterprises pulled back and private institutions developed the markets for mortgage-backed securities, these institutions competed to stake out their turfs in this new line of business, which held a prospect of high fees. In the competition for the mortgage originators' business, the imposition of quality standards for mortgages had lower priority - and, in the absence of guarantees of the sort that had been issued by Fannie Mae and Freddie Mac, the credit risks were passed on to the purchasers of the mortgage-backed securities.

\subsection{Flaws in Securitization: The Role of MBS Collateralized Debt Obligations}

As mentioned above, UBS was not so much involved in the securitization of mortgages as in the securitization of mortgage-backed securities themselves. As a latecomer in this line of business, coming from abroad, they may have been at a competitive disadvantage, relative to US investment banks, in establishing the relations to mortgage originators that would have been needed to get into mortgage securitization as such. By contrast, the securitization of mortgage-backed securities through MBS CDOs was seen as a significant revenue growth opportunity.

In contrast to the above assessment that mortgage securitization is, in principle, a good thing if incentive problems are kept under control, I have serious doubts about this second layer of securitization, i.e., the securitization of portfolios of mortgage-backed securities, rather than portfolios of mortgages. As I have outlined above, securitization can be useful because it provides the means for reallocating risks from where they originate to parties that are better able to bear them. In this operation, the packaging of securities is useful because the associated diversification of asset specific risks provides for standardization. The division of claims on the package into tranches that are ranked according to priority is useful if the originators hold on to the equity tranches and thus have the proper incentives to look after the quality of the portfolio they are securitizing. For the second layer of securitization, the benefits seem ephemeral, and the potential incentive effects large:

- If the first layer of securitization has been properly handled, the mortgagebacked securities as such should be eligible for inclusion in the portfolios of pension funds, life insurance companies and other investors that are better able to bear the risks associated with the long-term commitment of funds in real estate. To achieve this purpose, a second layer of securitization should not be needed.

- If the first layer of securitization has been properly handled, there should also be no significant benefits from additional diversification through 
a second layer of packaging. To be sure, a second layer of packaging will provide for additional risk diversification. However, if the mortgagebacked securities that are being packaged are themselves truly marketable, such diversification benefits could also be reaped by investors putting multiple mortgage-backed securities into their own portfolios. Transactions costs of their doing this on their own would probably not be much larger than the 120 or so basis points that UBS obtained as a fee for securitizing mezzanine mortgage-backed securities.

- As outlined in the UBS report, the division of claims into tranches with different priorities was not used to provide proper incentives. As a matter of fact, UBS Investment Bank held on to the senior tranches of MBS collateralized debt obligations and sold the junior tranches, including the equity tranches, in the open market. Given the belief that the senior tranches were safe, they did not have much of an incentive to look after the quality of the assets they were securitizing. The UBS report indicates that, indeed, they did not.

- To the extent that the second stage of securitization provided a ready market for the securities created in the first stage, it further diluted incentives for institutions handling the first stage to actively control the quality of the mortgages that they were packaging together. As the chain of financial intermediation became longer, the scope for moral hazard associated with such intermediation was increased.

An advocate for the creation of MBS collateralized debt obligations might object that these considerations neglect the role of regulation and certification. Regulation prevents certain institutional investors from acquiring securities that have low credit ratings or are unrated. For such investors and such securities, the argument that, once the securities are sufficiently standardized to be marketable, the investor can perform the diversification on his own would not be applicable. If statutory regulation requires a life insurance company to restrict its holdings to securities with credit ratings of $\mathrm{A}$ or better, this insurance company will not be able to acquire a diversified portfolio of mezzanine MBS with a credit rating of $\mathrm{BBB}$ or worse. If statutory regulation subjects banks to minimum equity requirements that are calibrated to the ratings of the assets they hold, the banks may find that a diversified portfolio of mezzanine MBS with a credit rating of $\mathrm{BBB}$ is too costly in terms of required regulatory capital. In these cases, one might argue that a second layer of securitization is useful because the additional diversification that it provides makes it possible to give an AAA credit rating to the senior tranche of a portfolio of $\mathrm{BBB}$ mezzanine $\mathrm{MBS}$ and therefore to make additional funds from such regulated institutions available for housing finance. The above criticism of this second layer of securitization would be moot because, even though the 
BBB mezzanine MBS are fully marketable, statutory regulation prevents some market participants from investing in these securities directly.

At this point, however, one must ask whether the second layer of packaging provides enough additional diversification to warrant an AAA credit rating for the senior tranche of a portfolio of BBB mezzanine mortgage-backed securities. This would only be reasonable if the returns on the different securities were sufficiently independent so that defaults on several of them at once were deemed much less likely than a default on any one of them, and the senior claim on the portfolio could in fact be considered to be safe. By contrast, if the returns on the different securities were correlated, the probability of defaults on multiple securities at once and therefore the probability of a default on the senior claim on this portfolio might not be so different from the probability of default on any one security. In this case, there would be no reason for giving an AAA credit rating to the senior tranche of a portfolio of BBB mezzanine mortgage-backed securities. ${ }^{50}$

The major credit rating agencies seem to have thought that securities were sufficiently independent to warrant high ratings for senior MBS collaterized debt obligations - until July 2007. Then, all of a sudden, in August 2007, they downgraded many of these securities and many of the underlying mortgagebacked securities. Most securities were not just downgraded by one grade, but by several grades, even by three or more grades. ${ }^{51}$ For corporate debt, such downgrading by several grades at once is almost unheard of. The fact that, in the summer of 2007 , there was so much downgrading by multiple grades suggests that the analysis underlying the previous ratings had been fundamentally flawed and that, at last, the rating agencies had come to realize this.

\subsection{Flaws in Risk Assessment: The Failure of the Rating Agencies}

For an outside observer, it is hard to tell what precisely has been wrong with the credit ratings of mortgage-backed securities before July 2007. I suspect that the risk models on which these ratings had been based were overoptimistic about default risks on the underlying mortgages and about correlations between the different mortgages and the different mortgage-backed securities. Both forms of overoptimism are related, and both have implications for the functioning of the second as well as the first stage of securitization.

There seems to have been a view that the individual borrower's ability to service his debt is of lesser importance if the property that serves as collateral

50 Duffie (2007) insists that MBS CDOs only make economic sense if the different MBS are sufficiently independent. He also warns that empirical estimates of correlations are notoriously unreliable. The criticisms voiced here apply a fortiori to higher stages of securitization, such as "CDO-squared" securities, where the collateral itself consists of MBS CDOs.

51 Dodd and Mills (2008). 
TABLE 1 - S\&P/CASE-SHILLER U.S. NATIONAL HOME PRICE INDEX (Q1 $2000=100)$

\begin{tabular}{llc}
\hline Q2 of Year & $\begin{array}{l}\text { S\&P/Case-Shiller US National } \\
\text { Home Price Index }\end{array}$ & $\begin{array}{l}\text { Rate of Change Over } \\
\text { Previous Year }\end{array}$ \\
\hline 2000 & 103.77 & $9.50 \%$ \\
2001 & 112.69 & $8.60 \%$ \\
2002 & 122.24 & $8.50 \%$ \\
2003 & 134.2 & $9.80 \%$ \\
2004 & 152.92 & $13.90 \%$ \\
2005 & 176.7 & $15.60 \%$ \\
2006 & 189.93 & $7.50 \%$ \\
2007 & 183.56 & $-3.60 \%$ \\
2008 & 155.32 & $-15.30 \%$ \\
\hline
\end{tabular}

Source: Standard \& Poors, see indices at http://www.standardandpoors.com.

for the loan is increasing in value. This view is actually corroborated by the finding of Demyanyk and Van Hemert, mentioned above, that, before 2006, the effects of the decline in the quality of mortgage borrowers were outweighed by the effects of increases in property prices. However, the view that property appreciation will reduce credit risk in a mortgage contract leads to an overoptimistic assessment of default risks if the property appreciation itself is overestimated. Moreover, if one fails to take account of the common factors that are driving real-estate prices, this view also leads to an overoptimistic assessment of correlations between the different borrowers' default risks. Both flaws came home to roost when, in mid 2006, real-estate prices in the United States began to turn down, and, as mentioned above, delinquency rates on recently issued mortgages rose to unprecedented levels.

The view that residential real estate was increasing in value reflected current and past experience. Table 1 documents the movement of real estate prices in the United States since 2000. The first column gives the value of the S\&P/Case-Shiller U.S. National Home Price Index at the end of the second quarter of each year. ${ }^{52}$ The second column translates these numbers into rates of growth over the preceding twelve months. From 1999 to 2003, realestate prices in the United States grew at roughly $9 \%$ per year. In 2003, their growth rate jumped, to $14 \%$ for $2003 / 2004$ and more than $15 \%$ for $2004 / 2005$. From 2005 to 2006, their growth was again slower. In June 2006, their growth turned negative, i.e., real-estate prices began to decline, first slowly and, then, from 2007 to 2008 , quite dramatically, by over $15 \%$. 
TABLE 2 - SELECTED INTEREST RATES IN THE UNITED STATES

\begin{tabular}{llll}
\hline Year & Federal Funds & $\begin{array}{l}\text { US Treasury } \\
\text { 10 Years }\end{array}$ & $\begin{array}{l}\text { Conventional } \\
\text { Mortgages }\end{array}$ \\
\hline 2000 & 6.24 & 6.03 & 8.06 \\
2001 & 3.88 & 5.02 & 6.97 \\
2002 & 1.67 & 4.61 & 6.54 \\
2003 & 1.13 & 4.01 & 5.82 \\
2004 & 1.35 & 4.27 & 5.84 \\
2005 & 3.22 & 4.29 & 5.86 \\
2006 & 4.97 & 4.80 & 6.41 \\
2007 & 5.02 & 4.63 & 6.34 \\
2008 & 2.00 & 3.89 & 6.48 \\
\hline
\end{tabular}

Source: Board of Governors of the Federal Reserve System, http://www.federalreserve. gov/releases/h15/.

A nationwide decline of residential real-estate prices like that of the past two years has not been experienced in the United States since the Great Depression, if then. To be sure, there had been a downturn in the early nineties, but this downturn had been concentrated in a few states and regions. At the national level, at that time, the S\&P/Case-Shiller U.S. National Home Price Index declined by no more than $4 \%{ }^{53}$ Following a few years of stagnation and sluggish growth, real-estate prices in the United States had again picked up speed in the late nineties. The experience of the early 2000's seemed to justify the view that real-estate prices could only go up.

However, any more detailed assessment would have suggested that the observed price increases had been driven by singular developments that could not be expected to go on forever. For example, there had been a significant decline in nominal interest rates in the United States. As shown in Table 2, the (short-term) Federal Funds Rate went from $6.24 \%$ to $1.13 \%$, the rate for ten-year Treasury Bonds from $6.03 \%$ to $4.01 \%$, and the rate for conventional mortgages from $8.06 \%$ to $5.82 \%$. This decline in interest rates must have given a boost to real-estate prices. However, it should have been clear that such a decline in interest rates could not continue forever, and might even be reversed, as indeed it was in 2005 and 2006. The boost that the decline in interest rates had given to real-estate prices should have been expected to be reversed if rates were to go up again.

Another development that should have been perceived as one-time, not to be repeated, involved the changes in arrangements for housing finance itself. 
Improvements in institutional arrangements for real-estate finance, like the securitization of mortgages, can and should cause real estate to appreciate. However, such an effect lasts only as long as perceptions of the new opportunities cause new and additional funds to flow into real-estate finance. It is bound to come to an end when financing structures have adjusted and real-estate prices have reached the new level that corresponds to the new structures.

Without a proper appreciation of the distinction between a one-time price increase and an ongoing appreciation process, ratings and investment decisions that are based on observed appreciations have elements of a bubble, in which observed price increases induce exaggerated return expectations, these return expectations in turn induce a further inflow of funds, this inflow of funds induces further price increases, and so on, until the bubble bursts because prices are too much out of line with any realistic valuations of the returns that the assets can actually generate. When the bubble bursts, the spiral is likely to be reversed as investors appreciate the risks to which they are exposed and try to get out of the assets that are now depreciating and thereby accelerate the depreciation itself.

It is probably not a coincidence that real-estate appreciation accelerated at roughly the time in 2003 when investment banks moved aggressively into mortgage securitization. At the time, market rates of interest were at their absolute minimum. Subsequently, when monetary policy became more restrictive and interest rates began to rise again, the effects of the expansion of mortgage finance seem to have even outweighed the effects of the interest rate increases. By mid 2006, real-estate prices were almost $90 \%$ higher than in the first quarter of $2000 .^{54}$ At this point, real-estate prices began to decline, and delinquency rates on mortgages began to rise.

The decline of real-estate prices since 2006 has affected almost the entire United States. Out of 20 metropolitan areas for which there are separate listings of the S\&P Case-Shiller Home Price Index, from mid 2006 to mid 2008, only one exhibits a noticeable price increase, ${ }^{55}$ three have approximately constant prices, and sixteen exhibit significant price declines; this latter group contains eight metropolitan areas with price declines exceeding $25 \%$. In the downturn as well as the upturn, housing prices across the United States were highly correlated. While I have not been able to find any data on this, I would expect delinquencies on mortgages to be similarly correlated. The correlations reflect the fact, that in the downswing, as well as the upswing, real estate markets across the United States were affected by the same changes in financing

54 By contrast, from 1994 to 2000 , the value of the index had increased by less than $30 \%$, from 78 to 100 .

55 Charlotte, North Carolina, $+5 \%$. 
conditions, namely changes in interest rates and changes in the availability of housing finance.

Given these observations, I suspect that, for a long time, the rating agencies failed to investigate the structure underlying the increases in real-estate prices since 2000 and that, therefore, they underestimated the probability of a downturn in real-estate prices and the associated danger for mortgage lenders. I also suspect that they underestimated the correlations in real-estate prices and in mortgage delinquencies. Both failures would explain why, for a very long time, they provided high ratings to mortgage-backed securities, sometimes quite far down to the bottom of the mezzanine level. An underestimate of correlations would also explain why they provided high ratings to the senior tranches of MBS collateralized debt obligations when the securities in the collateral had low ratings or even were unrated.

In this context, it is of interest to note that, in these activities, the rating agencies had a conflict of interest, not unlike the conflict of interest that had affected the performance of the "gate keepers" to the stock market, accounting firms and financial analysts, in the late nineties. Like the accounting firms then, the rating agencies had consulting branches, and these consulting branches were advising customers on how best to package mortgages or mortgage-backed securities and how best to tranche the claims for securitization. Too critical a stance in rating the resulting securities would have raised questions about the competence of the rating agency's consulting branch. Perhaps, the agencies, too, were fascinated with growth in this consulting business without properly appreciating the risks for their reputations and for the viability of their rating business. Perhaps also, they failed to appreciate that the lesson taught by the fall of Arthur Anderson in the wake of the Enron scandal might be relevant for credit rating agencies as well as accounting firms.

At this point, the credit rating agencies might insist that, in their analyses of credit risk for mortgages, mortgage-backed securities, and MBS collateralized debt obligations, they were using the most modern statistical and econometric techniques and that these analyses met any professional standard of risk analysis. I am, however, wondering whether, in this respect, they may not have been too professional, more precisely, too confident in the ability of quantitative empirical models to actually measure default probabilities and correlations. ${ }^{56} \mathrm{I}$ am sceptical about the power of statistics and econometrics in the sort of nonstationary environment that we have had in these years. My scepticism increases when I consider that, by contrast to price movements in organized markets, defaults on loans are relatively rare events for which it is difficult to have reliable statistics even in a stationary environment, and 
that, by their very nature, statistical assessments of correlations tend to be even less reliable. ${ }^{57}$

In short, I suspect that the UBS report's criticism of excessive confidence in quantitative methods of analysis at the expense of a "holistic" assessment of risks applies to the credit rating agencies as well as to UBS itself. In the case of the rating agencies, this failure was all the more serious as market participants were relying on their ratings, excessively so as the UBS report points out.

\subsection{Flaws and Biases of Internal Controls and "Market Discipline"}

There remains the question of who bought the mortgage-backed securities and MBS collateralized debt obligations and why. Again, a part of the answer is provided by the UBS report. UBS Investment Banking actually held on to the "super senior" tranches of the securities they created. Initially, they had also sold these tranches to investors in the market, but then, the managers in charge considered that the yields on these securities exceeded the costs that UBS was assessing for the requisite funds and decided to hold on to them in order to earn additional returns.

The risks involved in holding these securities were seriously underestimated. To some extent, they were hedged through insurance arrangements, but, because of overoptimism and an excessive reliance on the assessments of credit rating agencies, for most securities, the hedges covered only a fraction of the exposure; moreover, no attention was paid to the possibility that the counterparties to the hedges might themselves be in trouble and that this was most likely to happen at the very time when they would be called upon to step in and replace losses from borrower defaults. ${ }^{58}$ Also no attention seems to have been paid to correlations of risks on these securities with the risks involved in warehousing securities in the process of securitization. Indeed, once the credit risk of a position was hedged, this risk was deemed to be neutralized and did not appear any more in the quantitative risk analysis of the bank. In the actual course of events, these hedged positions were a major source of losses, partly because hedges were incomplete, partly because counterparties were in trouble.

57 This difficulty is also stressed by Duffie (2007).

58 The role of correlations between underlying risks and counterparty credit risks in hedging arrangements is discussed in Hellwig (1995). The problem appeared conspicuously in the Thai crisis of 1997 when international banks, which had tried to eliminate exchange rate risk by denominating loans in dollars rather than baht, found out that, after the devaluation of the baht, Thai entrepreneurs, who were earning money in baht, had difficulties servicing their dollar-denominated debts to Thai banks, which in turn then had difficulties servicing their debts to international banks. 
The UBS report conveys a picture of people who were frantic in the pursuit of returns while treating risk management and risk control as a matter of routine, to be handled by standard techniques, without much need for additional reflection. The report relates this picture to the use of incentive schemes that focus on short-run returns, with insufficient adjustment for risk and too little weight given to the long-run survival of the institution.

I suspect that the problem is not just one of incentive schemes. Incentive schemes and the prospects of high bonuses are just one of the factors that affect people's behaviours. One also has to take account of career concerns $^{59}$ and of peer pressure. If, as of 2005, one of the managers involved had questioned whether a large scale investment in MBS CDOs really made sense, he or she would have run the risk of becoming a pariah in the organization. If everybody in the reference group takes it for granted that a new business opportunity is highly profitable, the expression of scepticism is taken as a proof of ignorance and is likely to be withheld. Indeed, the fear of being ostracized can be contagious so that expressions of scepticism may be withheld even though many of the participants share them. ${ }^{60}$

Whether the style of discourse that is cultivated by the organization leaves room for effective expressions of scepticism or not is partly a question of how the organization is being run. This is where the UBS report's concerns about the failure of Senior Group Management to demand and the failure of UBS Investment Banking to provide a holistic risk assessment of mortgage securitization activities come in.

In part, however, this issue transcends the individual institution and involves the financial community as a whole. If the Chairman of the Executive Board of Deutsche Bank asserts that his institution must aim for a $25 \%$ annual rate of return on equity because such a return is the norm which "the market" expects from a leading bank, one may feel uneasy about the implications of this kind of targeting for the style of discourse and for the choice of strategy inside the institution, but one must realize that the external pressures to which he is referring are very real ones.

59 On career concerns, Schütz (1998) reports that, at the old UBS, Union Bank of Switzerland, which merged with Swiss Bank Corporation in 1997 to form the new UBS, the board member responsible for investments wanted to become CEO and knew that, to achieve this, he had to produce profits. In his domain of responsibility, the derivatives trading department in London provided 100 millions of Swiss francs one year and 150 millions the next year, while risk control was severely reduced. Shortly after he had actually become CEO, in 1997, the profits turned into 650 millions of losses!

60 For a detailed account of the argument, see Kuran (1995). In my contribution to Staub (1998c), I discuss the role of rhetoric and social interdependence in discourse as a source of contagion on the upswing, as well as the downswing. The experience of being treated as someone who clearly is not "with it" is one that I have often had in the nineties when I was suggesting that, with mortgage securitization, there might be a problem of moral hazard in origination; see also fn. 26. 
Over the past two decades, we have seen the rise of "market discipline" as a paradigm for corporate governance and of "shareholder value" as a key objective for the public corporation. Markets are said to impose discipline on corporate executives, inducing them to seek out profitable new ventures and to eliminate unnecessary costs in order to raise "shareholder value". The underlying mechanisms are not entirely clear; after all, "markets" as such are not actors in any sense, and market participants do not have strong rights to actually intervene in company affairs. ${ }^{61}$ Even so, "market discipline" seems to play a very effective role. I suspect that this role is based on the acceptance of "shareholder value", i.e., the market price of the company's stock, as a key concern in boardroom deliberations, and that acceptance of "shareholder value" as a relevant concern is due to the dependence of executive remuneration on stock prices. ${ }^{62}$ Corporate executives are then under pressure to satisfy the community of financial analysts, institutional investors, and the media because, in the very short run, this community's perceptions of the company determine stock price movements and stock price movements are important for the remuneration of many in the top layers of management. ${ }^{63}$

In such an environment, there is little room for deviating from the norms set by the expectations of financial analysts, institutional investors, and the media. If these norms are derived from the benchmarking of different institutions in the same sector, the bank as a whole is subject to peer pressure in the market just as its managers are subject to peer pressure inside the organization. If other banks exhibit high growth in an innovative business activity like the securitization of mortgages and if financial analysts and institutional investors take this as a benchmark in assessing one's bank, there is little room for questioning the implications of this growth for risk. If other banks are earning a $25 \%$ rate of return on equity and if financial analysts and institutional investors take this as a benchmark in assessing one's bank, there is little room for questioning this benchmark.

In particular, there is no room for asking what risks are taken in order to achieve the $25 \%$ rate-of-return benchmark. From the theory of capital markets, we know that, on average, higher rates of return can be achieved by

61 Indeed, at the very time when it was becoming politically correct to refer to "shareholder value" in boardroom discussions, in the early nineties, corporate management in the United States, with the support of state legislatures and the courts successfully installed measures that all but eliminated hostile takeovers and made it all but impossible for outside shareholders to interfere with the corporation against the wishes of management; see Useem (1993).

62 For a detailed, critical discussion of "market discipline", see Hellwig (2005).

63 This interpretation of "shareholder value" rhetoric as a justification of managerial enrichment raises the question why "shareholder value" did not play much of a role before 1990 . Possibly, the opportunities and the needs for corporate restructuring that became apparent in the eighties and that have been pursued all through the nineties shifted the balance from a system involving remuneration through power and incumbency to one involving remuneration through a share in the profits from restructuring. 
pursuing riskier strategies. If two assets have the same expected return, but one is riskier than the other, the riskier asset must trade at a discount relative to the safer one. On average, therefore, the rate of return on the riskier asset is higher. Quite possibly, therefore, the reported 25\% rate-of-return benchmark for leading banking institutions reflects risk taking as well as efficiency. Perhaps also these institutions have simply been "economizing" on equity, using a small capitalization to support a large volume of activity. After all, we have seen the equity of institutions like Deutsche Bank or UBS going down from somewhere near $10 \%$ of their overall balance sheets in the early nineties to somewhere between 2 and $3 \%$ in the recent past.

An adherent of "market discipline" will object that, surely, markets take account of the risks that a bank is taking and will penalize the bank if these risks are excessive. From this perspective, the relative decline in bank equity should be regarded as a source of efficiency gains, enabling the bank to expand its business and thus make better use of the equity capital that it has. If the strategy did involve undue risk taking, stock prices would have been depressed, and management would be penalized.

I am sceptical about this argument. I have yet to see an analyst's or a journalist's report commenting on the risks of a bank's strategy as well as the returns that this strategy has yielded over the preceding year. I have yet to see such a report questioning the risk implications of a bank's "economizing" on equity. To be sure, when the risks come home to roost and the institution is in trouble, everybody comments that its strategy has been too risky. However, beforehand, at the time when the strategy is being implemented, such comments are rare. There is a reason for this: Returns are relatively easy to measure and to communicate to the audience that one is addressing. Risks are difficult to measure and even more difficult to communicate. ${ }^{64}$ I therefore believe that "market discipline" as a mechanism of corporate governance is intrinsically biased in favour of strategies that involve greater risk taking. ${ }^{65}$

64 This argument is closely related to the argument of Holmström and Milgrom (1991), that, if there are several dimensions to managerial effort, in this case, expected returns and risks, the provision of strong incentives in one dimension may counterproductive in another dimension, where performance measurement is subject to greater uncertainty.

65 From a welfare perspective, I would add that the risk concerns of shareholders are not the same as the risk concerns of creditors and that a system of "market discipline" that is driven by shareholder interests alone is likely to induce excessive risk taking in the sense that risks for creditors, depositors and deposit insurance are not given sufficient weight. The literature on "market discipline", e.g. Calomiris and Kahn (1991) or Calomiris (1999), does have models of "market discipline" by depositors, as well as shareholders, but I have yet to see an analysis of "market discipline" by different groups of investors with conflicting interests. 


\subsection{Yield Panic}

Among the investors in mortgage-backed securities or MBS collateralized debt obligations, we also find many that were not subject to "market discipline". State-owned banks from Germany were "sponsoring" American entities, so-called "conduits" and "structured investment vehicles" that invested large amounts of money in subprime-mortgage-backed securities. Private investors and non-financial institutions put money into hedge funds that bought equity tranches of such portfolios of mortgages or mortgage-backed securities.

These market participants seem to have been driven by what I would like to call yield panic. The past decade has been a period of low interest rates, real as well as nominal, and of low interest margins for financial intermediaries. For many investors and many financial institutions, this raised the problem of how to earn the returns that they needed to cover their expenses. An example is provided by the Landesbanken, state-owned banks in Germany, which were major buyers of mortgage-backed securities. In the past, the Landesbanken had thrived because the state guarantees that they had gave them an AAA rating, which allowed them to refinance themselves at very low rates of interest. When the European Commission banned the state guarantees as state aid violating the EC Treaty, their refinancing costs rose and their interest margins all but disappeared. With at best weak market positions in retail banking markets and in lending to industry, they had lost their business model and were looking for new ways to how to earn the money that they needed to cover their expenses. For them, the extra basis points that were offered by mortgage-backed securities looked very attractive.

In a constellation with low interest rates and low interest margins, the fear of not being able to earn the returns that one needs can easily induce an investor to abandon the caution with which he would have proceeded in normal times. Whereas one usually thinks of investment excesses as being the result of irrational exuberance, i.e., excessive optimism, one should appreciate that fear can be just as powerful. If the long-term interest rate stands between 4 to $5 \%$ and you refinance yourself at rates between 3 or $4 \%$ there isn't much of a margin on which to cover your costs and earn a return on equity. At that point, a premium of some 50 basis points, i.e., half a percentage point per annum, on a mortgage-backed security may be very tempting. If this security has a rating of AAA or AA, i.e., it has been certified by the rating agencies as being extremely safe, there really is no risk involved, or is there?

The investor might still have asked himself why the security carried a premium of 50 basis points at all. After all, a premium of 50 or so basis points owed its existence to the fact that, even though they had the same credit ratings, these securities were not deemed to be the equivalent of an AAA or AA government bond. However, to cite a market participant: "Who is going to do 
a due diligence for just a few basis points?" This would have been very costly, perhaps even impossible, given that a typical mortgage-backed security might be backed by a package of some 30.000 individual mortgages. Moreover, it might have shown that this opportunity to earn extra returns was not so innocent after all. Investors preferred to be satisfied with the ratings that had been provided by the rating agencies. There were hardly any additional assessments of these securities' risks.

Concerns about returns and yields also motivated the many private investors and nonfinancial institutions who put their money into hedge funds and private-equity firms in these years. The drastic growth of these institutions in the years since 2000 must be ascribed at least partly to the frantic search for yield in a world of low interest rates and depressed stock markets. ${ }^{66}$ In this world, hedge funds and private-equity firms held out the promise of additional returns based on the managers' ability to capture the "alpha" factor associated with asset-specific prospects if only it was possible to discern and to realize them. However, if I look at the information that these institutions provided, I wonder as to what the investors thought they were doing. The notion that a fifty-million-dollar investor "has a right to one telephone call a year" is not unheard of. The fact that investors were willing to put up with something like this is itself a testimony to their, too, having been affected by yield panic.

Hedge funds enter the present story because, along with investment banks, they were buying the equity tranches of portfolios of mortgages or mortgage-backed securities. ${ }^{67}$ As I explained above, negative incentive effects of mortgage securitization on mortgage origination would have been contained if equity tranches had been held by the institutions that originated the securities, requiring them to bear the brunt of any default on the underlying mortgages. As markets developed, however, the obsession of investors with high yields created a market for the equity tranches as well as the more senior tranches. Regulated institutions were barred from buying these unrated securities, but hedge funds and investment banks, being unregulated, were eager to avail themselves of the high yields that the equity tranches seemed to offer. ${ }^{68}$ Private investors and non-financial institutions were eager to participate in these high yields. Little attention seems to have been paid to the moral hazard in origination and securitization that was thereby induced or reinforced.

66 According to Crockett (2007), total funds managed by hedge funds more than doubled between 2002 and 2006, growing from under 800 billion dollars to around 1600 billion dollars, at an annual rate of roughly $19 \%$.

67 Dodd (2007), Kiff and Mills (2007).

68 Duffie (2007). 


\subsection{A Summary Assessment of Subprime Mortgage Securitization}

Putting the different pieces of the puzzle together, one obtains the following picture: In the years since 2000, with low interest rates, low intermediation margins, and depressed stock markets, many private investors were eagerly looking for securities offering better yields and many financial institutions were looking for better margins and better fees. The focus on yields and on growth blinded them to the risk implications of what they were doing. In particular, they found it convenient to rely on the rating agencies assessments of credit risks, without appreciating that these assessments involved some obvious flaws. Given the hunger of investment banks for the business of securitization and the hunger of investors for high-yielding securities, there was little to contain moral hazard in mortgage origination, which, indeed, seems to have risen steadily from 2001 to 2007 . For a while, the flaws in the system were hidden because real-estate prices were rising, partly in response to the inflow of funds generated by this very system. However, after real-estate prices began to fall in the summer of 2006, the credit risk in the underlying mortgages became apparent.

For purposes of analysis, it is useful to distinguish between errors of judgment and flaws in governance. Errors of judgment are unavoidable, and one can at best hope to contain the implications of such errors for others. Flaws in governance, by contrast, can be avoided if enough attention is paid to the governance implications of the structures that one is developing. I see the following major flaws in governance:

- Because the institutions responsible for origination did not hold any equity shares, they did not have much of an incentive to take care in borrower creditworthiness assessments. Similarly, following the retrenchment of Fannie Mae and Freddie Mac, the institutions involved in securitization did not have much of an incentive to impose and enforce creditworthiness standards to be met by originators. ${ }^{69}$ Both, originating and securitizing institutions, were more interested in volume than in quality control.

- Too much depended on the rating agencies' assessments. This dependence was partly due to statutory regulation requiring certain insurance companies or pension funds to only hold AAA or AA rated securities or to statutory regulation making bank capital requirements depend upon these ratings. Too little attention was paid to the conflict of interest that arose because the rating agencies were providing consulting services on the very things that they were also rating.

69 By contrast, Fannie Mae and Freddie Mac providing guarantees for the securities that they put on the market had incentives to maintain standards for prime mortgages. This is also true for the German Pfandbrief system where the issuance of the Pfandbrief, a mortgagebacked security, does not eliminate the liability of the originator or the issuer. 
- Mechanisms of corporate governance and incentives, external ("market discipline") as well as internal ("internal risk control"), were too weak to force the people in charge of actually doing things to provide a comprehensive account of the implications of their activities for the overall risk exposure of the institution. Possibly also, the separation of cultures between investment bankers and credit officers reduced the awareness of credit risks on the side of the investment bankers who were involved.

The second of these flaws, together with a failure to understand the relevant correlations, seems to have been mainly responsible for the growth of the markets in MBS collateralized debt obligations (MBS CDOs) and MBS $\mathrm{CDO}$ collateralized debt obligations ("MBS $\mathrm{CDO}^{2}$ ), which otherwise would not have had any raison d'etre. The existence of these markets in turn created an easy outlet for low-quality mezzanine securities and thereby enhanced the problem of insufficient risk control in origination and in the first stage of securitization.

\section{SYSTEMIC RISK IN THE CRISIS}

\subsection{Why Did the Subprime-Mortgage Crisis Bring Down the World Financial System?}

Given the flaws in the system of subprime mortgage finance and securitization in the United States, the collapse of this system should not have come as a surprise. Indeed, long before the outbreak of the crisis, quite a few observers had warned that residential real-estate markets were experiencing a bubble and the only question was when the bubble would break. ${ }^{70}$ However, the flaws in subprime mortgage finance and securitization and the collapse of this system provide only one part of the explanation for the current financial crisis. They cannot explain why, since August 2007, the fallout from the subprime mortgage crisis has shaken the entire financial system of the world. This development has taken everybody by surprise.

Even in the spring of 2007, when market participants and regulators were already aware that subprime-mortgage markets in the United States were in a state of crisis, nobody yet seems to have anticipated the repercussions that were to follow. For instance, the International Monetary Fund's Global Financial Stability Report of April 2007 gives a fairly detailed account of problems with subprime mortgages and mortgage-backed securities in the United States, but concludes that the problem would not affect the rest of the financial system. Citing the results of stress testing by investment banks, the report suggests that, even if housing prices in the United States were to

70 From Robert Shiller, one of the creators of the S\&P/Case-Shiller real-estate price indices, such a prediction is reported in Barrons, June 2005. 
decline by $12 \%$ per year for five years in a row, AAA- and AA-rated subprime-mortgage-backed securities, some $85 \%$ of the total issue, would not be affected at all - "this suggests that the amount of potential credit loss in subprime mortgages may be fairly limited."71

One might object that, being based on stress testing by investment banks, this assessment in April 2007 was vitiated by the very flaws in risk modelling that had enabled the growth of subprime mortgage finance in the first place. However, even with a more realistic or a more pessimistic view about subprime mortgages, there is a puzzle because the overall volume of this market was not all that large. The 2007/2008 Annual Report of the Bank for International Settlements (BIS) expresses the puzzle well when it asks: "How could problems with subprime mortgages, being such a small sector of global financial markets, provoke such a dislocation?"

As mentioned in the introduction, the IMF estimates that the total volume of non-prime mortgage-backed securities in the United States amounts to some 1.1 trillion dollars. ${ }^{72}$ In absolute terms, this is a large number. However, this number amounts to less than one fifth of the value of all residential mortgage-backed securities in the United States (5.6 trillion dollars), less than one tenth of the value of all residential mortgages in the United States (13 trillion dollars), less than one twentieth of the value of residential real estate in the United States (20-30 trillion dollars), and presumably less than one fortieth of the value of total private wealth in the United States. ${ }^{73}$

More to the point, the estimated 500 billion dollars of losses in non-prime mortgage-backed securities are much smaller than stock market losses after the burst of the technology bubble in $2000 ;{ }^{74}$ they are also smaller than the

71 International Monetary Fund (2007, p. 7). In a similar vein, the 2006/2007 Annual Report of the Bank for International Settlements (BIS), published in June 2007, mentions the subprime mortgage crisis as a threat for financial stability, without, however, conveying any sense of urgency. In late June, at the 6th Annual BIS Conference, on "Financial System and Macroeconomic Resilience", nobody, myself included, seems to have had an inkling of the crisis that was about to unfold.

72 The April 2007 Global Financial Stability Report of the IMF gave an estimate of 824 billion dollars of subprime mortgage-backed securities; I cannot tell whether the difference between the more recent estimates and this one is due to growth in 2007 or to the inclusion of Alt-A along with subprime mortgage-backed securities.

73 Comparisons are made on the basis of numbers given in International Monetary Fund (2007) and Slacalek (2006).

74 For US stocks traded on the New York Stock Exchange alone, stock market capitalization declined from 11.5 trillion dollars at the end of 1999 and at the end of 2000 to 11.0 trillion dollars at the end of 2001 and to 9.0 trillion dollars at the end of 2002; for US stocks traded on NASDAQ, the decline went from 5.2 trillion dollars at the end of 1999 to 3.6 trillion dollars at the end of 2000, 2.7 trillion dollars at the end of 2001, and 2.0 trillion dollars at the end of 2002. Data are taken from the World Federation of Exchanges at 
$600-800$ billion dollars of losses that, at the peak of the S\&L crisis around 1990, were guesstimated as losses of the US savings and loans industry. Yet, the effects of the burst of the stock market bubble and of the S\&L crisis on the global financial system were rather more limited; in the case of the S\&L crisis, these effects were hardly noticeable. Why then has the impact of the subprime mortgage crisis on the rest of the financial system been so much more severe?

The difference between these other crises and the subprime mortgage crisis is not in the magnitude of the primary losses, but in the systemic linkages and repercussions. In the stock market decline of the early 2000's, the brunt of the burden was borne by final investors, either directly, or through the values of their holdings in pension funds and the like. In the S\&L crisis, the failing institutions were taken over and closed by the government; the depositors were paid off, and the assets were disposed of without undue haste. In each case, financial institutions other than the ones that were immediately implicated had to adjust to changed circumstances, ${ }^{75}$ but they did not have to shoulder significant portions of the actual losses. By contrast, in the subprime mortgage crisis, there has been no surgical separation of failing assets and failing institutions from the rest of the financial system.

In the following, I will argue that the overall impact of the crisis on the world financial system is due at least as much to the incidence of systemic risk as to the difficulties with subprime mortgages themselves. I will also argue that there were serious flaws in financial system architecture and that these flaws have greatly magnified the effects of the subprime mortgage crisis. Lack of transparency meant that the extent of systemic risk exposure could not be foreseen by the participants. In thinking about lessons for the future, therefore, we need to go beyond considerations of governance and individual incentives and pay attention to systemic interdependence and transparency.

The incidence of systemic risk over the past year has been due to the interaction of unsound banking practices, an excessive reliance on markets, and market malfunctioning in the crisis. In the remainder of this section, I will explain these flaws, their origins and their effects, and indicate how they interacted in the crisis.

Footnote 74 continued

http://www.world-exchanges.org/publications/TA1300.pdf, http://www.world-exchanges.org/ publications/TA1301.pdf, and http://www.world-exchanges.org/publications/TA1302.pdf.

75 For instance, the S\&L crisis eliminated US saving institutions as buyers of junk bonds that served to finance hostile takeovers. Together with high interest rates, this contributed to the end of the takeover wave in 1989; the insolvency of Drexel, Burnham, Lambert seems to have been the main "domino effect". 


\subsection{Excessive Maturity Transformation}

The major surprise of the past year has been the extent of leverage and of maturity transformation in real-estate finance on the basis of mortgagebacked securities. Whereas, in previous years, most discussions about financial stability had focussed on hedge funds and their leverage, the leverage of hedge funds, on the order of $50 \%$ on average, was dwarfed by the leverage of the conduits and structured investment vehicles (SIVs) that had been set up by the banking industry for the purpose of investing in asset-backed securities. Here, leverage ratios close to $100 \%$ were the rule, rather than the exception. Moreover, while these institutions were investing in long-term securities, they refinanced themselves by issuing asset-backed commercial paper, i.e., very short-term debt, and were in constant need of refinancing. ${ }^{76}$

In Section 2 above, I have explained that such maturity transformation is a major source of risk for the institution that engages in it. It is also a major source of systemic risk. If there is any shock to the availability of funds for refinancing, the individual institution is in trouble because it needs funds to repay its short-term debt. If it cannot find an alternative source of finance, it must have a fire sale of its long-term assets. This fire sale depresses the assets' prices in the market. The decline in the assets' prices puts pressure on all institutions that hold such assets. Under mark-to-market accounting, the other institutions will be forced to recognize losses immediately. Even if they do not recognize the losses immediately, it suffices that market participants know that these institutions hold such assets and begin to have doubts about them. If such doubts induce investors to withdraw their funds from these other institutions, there may well be a chain reaction, in which one domino falls after the other. Such a chain reaction can occur even if there is no doubt about the underlying long-term assets; any shock to the confidence of investors in the refinancing markets can trigger it.

Since August 2007, we have been observing precisely such a process of chain reactions. In that month, the system of holding long-term asset-backed securities through conduits and SIVs that were refinanced in the commercial paper market broke down. At the time, this system held about 1 trillion dollars worth of long-term securities, ${ }^{77}$ equivalent to some $90 \%$ of subprime mortgage-backed securities or some $17 \%$ of all mortgage-backed securities. The breakdown of this system contributed to the implosion of markets for these securities and the subsequent spread of the crisis through the entire financial system, which greatly magnified the overall impact of the subprime mortgage crisis.

76 A detailed description of conduits and SIVs is provided in Chapter 3 of the IMF's Global Financial Stability Report in April 2008.

77 Dodd and Mills (2008). 
The breakdown was triggered by the rating agencies downgrading various asset-backed securities by several grades at once and by two hedge funds trying to cut their losses by liquidating such securities. Both events raised serious questions about the securities' values and about the solvency of institutions that were holding them, in particular, conduits and SIVs that did not have any equity worth speaking about. These questions were quickly extended to cover the money market funds that had been investing in the commercial paper of conduits and SIVs. The French bank Paribas suspended withdrawals from its money market funds on the grounds that the values of the funds' assets could not be properly determined. Most money market funds then feared withdrawals from their investors as well as losses from their loan clients and moved out of the commercial paper of conduits and SIVs. These institutions then found themselves in a situation not unlike that of the US savings and loans institutions in 1980, before the deregulation of deposit rates, when depositors left them in droves to place their money with money market funds and they were at a loss as to how to refinance the long-term mortgages in their portfolios.

Many conduits and SIVs actually had fallback promises of liquidity assistance from the banks that had sponsored them. However, this liquidity assistance did not cover all refinancing needs so that some fire sales had to occur anyway. Moreover, in view of the sad state of the markets for the assets held by conduits and SIVs and in view of the large amounts that were involved, the assistance that these institutions obtained from their sponsors raised doubts about the sponsors themselves.

Some of the sponsors, like Industriekreditbank (IKB) or Sächsische Landesbank in Germany, each with double-digit-billion dollar stakes in these operations, found that the liquidity assistance to which they were contractually committed - and the losses that this assistance would entail - by far exceeded their capacity to bear losses. Their commitments to the conduits they had sponsored in fact amounted to more than four times their own equity; the losses inherent in these loan commitments to insolvent institutions were sufficient to bankrupt them. Industriekreditbank managed to avoid bankruptcy only because its corporate mother, the federally owned Kreditanstalt für Wiederaufbau, provided new equity capital in what was then thought to be a large amount. For Sächsische Landesbank, the State of Saxony as owner had to underwrite the recognized losses before selling the bank. Without the owner's willingness to provide compensation for the losses, these banks would have gone under right away.

Market participants, as well as outsiders, were very much surprised by these developments. To be sure, market participants knew all along that conduits and SIVs had been used to invest in asset-backed securities. They also 
knew that sponsoring banks were committed to provide these institutions with liquidity if refinancing through the market broke down. However, they do not seem to have had much of an idea as to the scope of these operations - in terms of aggregates as well as their implications for the sponsoring banks. The fact that around 1 trillion dollars worth of securities were held by conduits and SIVs does not seem to have been known. The fact that the sponsoring banks' commitments were high enough to bankrupt these banks was not known either. Given the banks' assessments that these commitments were not likely to be called upon, they had not appeared in their balance sheets. Only when the conduits needed them were the banks forced to lay them open, all at once revealing their implications for bank solvency.

The surprise that was thus generated itself affected the market participants' further reactions. If I see a bank in trouble because of commitments that I had not known about, I wonder whether Bank X may be in a similar situation. After all, didn't Bank X also have a stake in MBS CDOs? And didn't they also make a commitment of liquidity assistance to some conduit or SIV? Given the revelations that have just been made about Bank Y, I must expect that Bank X may have a multi-billion dollar skeleton in its closet, and should therefore refrain from doing any business with Bank X.

This kind of reaction explains the almost complete drying up of interbank markets in August 2007 and on repeated occasions since then. The breakdown of refinancing was thus not limited to conduits and SIVs, but affected the entire worldwide banking system. It was particularly damaging to independent investment banks and similar institutions that rely on the open market rather than depositors for most of their funding.

Massive central-bank interventions, in August 2007 and later, have tried to substitute for the missing liquidity in markets. However, the central banks could not provide more than a stopgap. Short of buying the securities themselves, the central-bank intervention could not eliminate the systemic problem that, with the breakdown of conduit and SIV refinancing, there was a large overhang of long-term asset-backed securities that needed refinancing at a time when the fundamental value of these assets was questionable and the associated risks were seen as a potential threat to any institution that was holding them.

\subsection{Market Malfunctioning in the Crisis}

Even if there had been no doubts about the quality of asset-backed securities, the breakdown of the maturity transformation of conduits and SIVs would have caused a significant adjustment in the markets for these securities, driving security prices down as investors would ask for higher maturity premia 
and higher risk premia to hold the assets that conduits and SIVs were no longer able to refinance. ${ }^{78}$ Given the uncertainty about the quality of assetbacked securities, the adjustment had to be all the more severe.

As the crisis unfolded, participants in the various relevant markets behaved as one would expect them to behave when there is significant apprehensiveness about the quality of the assets, the quality of counterparties, and the evolution of the financial system in the near future. They withdrew funding and insisted on large discounts on any assets of unknown quality.

To some extent, this behaviour can be seen as an instance of Akerlof's 'lemons' problem: In a crisis situation, in which there is asymmetric information about the quality of assets that are being traded, any potential investor must fear that the seller is trying to unload his rotten apples while keeping the good ones. Similarly, with asymmetric information about the solvency of a potential borrower, any investor must fear the rotten apples in the borrower's portfolio. To protect himself against this danger, he refuses to buy the assets or to provide a new loan. At the very least, he insists on a large discount.

In a crisis, such reactions can also involve an element of panic. Given the surprises that they just experienced with the multiple-step downgrades of mortgage-backed securities by the rating agencies and with the discovery of large-scale maturity transformation by conduits and SIVs, investors may have been wondering what other surprises might be in store for them. Institutional investors, e.g., the managers of money market funds and hedge funds may also have been wondering how their own financiers would react to the news. Anyone who had to fear his own financiers' reactions would have felt compelled to reduce risks and increase liquidity in his own portfolio.

Given these considerations, we should not be surprised by the IMF's assessment ${ }^{79}$ that market prices seem to have dropped significantly below the expected present values of future cash flow from the mortgage borrowers or their properties. As mentioned in the introduction, a simple back-of-the-envelope calculation indicates that, for market values of mortgage-backed securities to be in line with discounted present values of future cash flow from the mortgage borrowers or their properties would require an expectation that property values will decline by $45-50 \%$. Given that, until June 2008, the average actual decline had been 19\% and no metropolitan area had seen declines

78 Table 1 above shows that, even for conventional mortgage, risk premia have gone up dramatically, By 2008, the spread between conventional mortgages and 10-Year Treasuries has risen to 259 basis points, approximately a hundred basis points higher than in the years 2004 2006 and still more than fifty basis points above its previous maximum in 2000 .

79 International Monetary Fund (2008a). 
above $33 \%,{ }^{80}$ such an expectation would seem to be extraordinarily pessimistic. $^{81}$

The notion that the market values of securities may be significantly below the expected present values of future cash flows from these securities seems incompatible with the theory of asset pricing in informationally efficient markets. However, the contradiction is apparent rather than real. Any notion that asset prices should correspond to expected present values of future cash flows presumes (i) that the parties holding these expectations have sufficient funds to bet on their expectations by taking long positions and (ii) that little attention needs to be paid to risk premia and liquidity premia. If limitations of funds or worries about refinancing prevent participants from taking long positions, there is no reason why market prices of assets shouldn't fall significantly below expected present values of future cash flows. ${ }^{82}$ Indeed, theoretical analyses have shown that at a time when long-term investments have been sunk and reserves of liquid assets are scarce, market reactions to even small shocks can be quite extreme as market participants fear for their own viability and hoard liquidity. In such situations, investors may require very large discounts before they are willing to acquire long-run assets. ${ }^{83}$ In the real world, such effects are reinforced by 'lemons' concerns, as well as the element of panic that follows a dramatic surprise, when important assumptions underlying one's world view have just been refuted.

This malfunctioning of markets in a crisis is one reason why receivers usually find it important to take time to unwind the positions of bankrupt institutions. Going back in history, we find that, by 1997, after the Swedish banks had been reprivatized, the losses from the crisis of the early nineties were deemed to be about half as large as had been expected in 1992, when the

80 Phoenix, Tampa, and Miami had price declines just below 33\%. Four metropolitan areas had declines between 25 and 30\%; quite a number had declines of $10 \%$ or less. See indices at www.standardandpoors.com. In any case, these cross-regional variations in real-price declines should not matter if proper attention has been paid to cross-regional diversification in the formation of packages of mortgages for securitization.

81 To be sure, loss rates on mortgages and mortgage-backed securities will depend on correlations as well as averages. Borrowers with below-average down payment rates or borrowers with above-average declines in property values are more likely to default than others. However, if the reliance on averages introduces a downward bias into the back-of-the-envelope calculation in the introduction, there also is an upward bias from my treatment of the borrower's equity position: The $5 \%$ equity share that I assumed lies below the $6 \%$ average down payment rate of subprime mortgage borrowers and below the $12 \%$ average down payment rate for Alt-A mortgage borrowers. Further, until the summer of 2006, property values had been going up. For the average property purchased in 2004, the borrower's equity as of 2006 would have risen by more than fifteen percentage points, for one that had been acquired in 2005 the increase would still have amounted to roughly seven percentage points.

82 Shleifer (2000).

83 Allen and Gale (2004a,b). 
crisis broke into the open. ${ }^{84}$ By 1998 , losses from the savings and loans crisis in the United States were assessed at 160 billion dollars, less than a third of the $600-800$ billion US dollars that were talked about around $1990 .{ }^{85}$

\subsection{The Role of Fair Value Accounting}

Market malfunctioning in the crisis would not have mattered if institutions had been independent of markets. In fact, the exposure of financial institutions to what was happening in markets has been much greater in this crisis than in previous ones. To the extent that financial institutions need markets for refinancing, some dependence on markets can always be taken for granted.

However, in the present financial crisis, the system of mark-to-market or fair value accounting has created an additional channel through which market events influence the well-being of financial institutions. Under this system, financial institutions value the assets that they hold at those prices at which they could sell them in the market if they had to sell them immediately. In cases where markets for the securities are not functioning, market prices of securities with similar characteristics are used as a standard of reference. In cases where markets for securities with similar characteristics are also not functioning, econometric models are used to provide estimates of what the securities could be traded for if the markets were functioning.

Under this regime, the institution in question cannot just claim that it wants to hold the security until maturity and that balance sheet valuations should therefore rely on assessments of fundamentals, rather than market valuations. The fact that, in this crisis, asset-backed securities have probably been substantially undervalued by markets is quite irrelevant for the institutions' accounts. $^{86}$

The introduction of fair value accounting was motivated by the experience of the savings and loans crisis in the United States. As mentioned in the introduction, in the early eighties, savings and loans institutions in the United States were carrying long-term mortgages with fixed interest rates of $6 \%$ p.a. at face value in their books even when market rates of interest were around $15 \%$. In the absence of fair value accounting, they did not have to acknowledge that, at current market rates of interest, the discounted present value of the debt service they could expect was much below the face value of these mortgages. The fact that, because of this discrepancy, the greater part of these institutions was technically insolvent, in the sense that the discounted present

84 Englund (1999).

85 Curry and Shibut (2000).

86 For systematic discussions of fair value accounting and the issues it raises, see the Chapter 2 of the April 2008 issue and Chapter 3 of the October 2008 issue of the IMF's Global Financial Stability Report (International Monetary Fund 2008a,b). 
value of the debt services they could expect was below their liabilities, never was acknowledged in their balance sheets. Technically insolvent institutions were left to "gamble for resurrection". With fair value accounting, those longterm mortgages with fixed interest rates of $6 \%$ would have been written down to acknowledge the decline in discounted present values of future debt service. Insolvencies would have been acknowledged in the early eighties already, and the resolution of the crisis would have been much less costly.

More generally, if financial institutions carry assets at market values or "as-if" market values, they are forced to quickly acknowledge adverse developments and to take corrective actions without undue delay. Indeed, with proper incentives for the institution's financiers, shareholders and creditors, fair value accounting is deemed to provide the information that is needed for these financiers to exert "market discipline" so as to induce the needed corrections. ${ }^{87}$

However, such "market discipline" is problematic if the markets in question are not functioning well. If, as discussed above, the market value of a security is below the expected present value of its future cash flows, a system of mark-to-market accounting induces a write-off which is appropriate only if the bank wants to liquidate the security and is unnecessary or at least excessive if the bank wants to hold the security to maturity. As I discussed before, such discrepancies between expected present values of future cash flows and market prices are likely to arise in a financial crisis - and seem to have affected subprime mortgage-backed securities on a large scale.

In such situations, a reliance on fair value accounting is problematic. The ensuing write-offs will force the bank to take corrective actions. Given the decrease in book equity that such write-offs induce, the corrective actions are likely to involve some deleveraging, i.e. some sale of assets to reduce leverage. If the assets in question are the very assets for which markets are not functioning, the book losses turn into real losses, which they might not have done if the bank could have held on to the assets. ${ }^{88}$ When the IMF is suggesting that, in the present crisis, market values of assets may not provide the right signals "for making long-term value-maximizing decisions", 89 it is pinpointing this very problem.

Presumably, an institution's accounting system should provide the institution's management with proper guidance for choosing value-maximizing

87 The classic theoretical piece on "market discipline" for banks is Calomiris and Kahn (1991); for policy recommendations, see, e.g., Calomiris (1999). The conflict between "market discipline" by shareholders and "market discipline" by creditors, which I discussed in fn. 65 above, plays no role in this literature.

88 For theoretical treatments of the problem, see Allen and Carletti (2006, 2008), Allen and Gale (2006).

89 International Monetary Fund (2008a, pp. 65f). 
decisions. In a crisis situation in which markets are not well functioning, fair value accounting is not suitable for this task.

The problem transcends the individual institutions. If book losses under fair value accounting force a bank to take corrective actions, these actions themselves will feed back into the financial system. ${ }^{90}$ The bank's attempts to adapt its activities to its reduced book equity position and therefore to scale down its asset holdings will put additional strain on markets and reinforce the downward pressure on asset prices. The combination of market malfunctioning and fair value accounting thus can have strong, mutually reinforcing, procyclical effects, deepening the financial crisis and inducing a downward spiral in the financial system.

\subsection{The Insuffiency of Bank Equity Capital}

The procyclical effects of market malfunctioning and fair value accounting were and continue to be reinforced by the insufficiency of equity buffers in financial institutions. This insufficiency appears in several guises. First, the hidden banking system of conduits and SIVs was operating with hardly any equity at all. They had no buffers to absorb the shock of July/August 2007. Some buffers were provided by sponsoring banks, especially those that decided to integrate their conduits or SIVs into their own balance sheets. However, these support operations raised questions about the sponsoring banks' own equity positions.

Second, banking institutions worldwide have been "economizing" on equity. In order to earn as high a rate of return on equity as possible, they have greatly expanded the scale of operations that the equity base would support. As I have already mentioned, the equity positions of institutions like Deutsche Bank or UBS have therefore gone from somewhere near $10 \%$ of their overall balance sheets in the early nineties to somewhere between 2 and $3 \%$ in the recent past.

This relative decline of equity positions concerned the capital that banks held in fulfilment of capital adequacy requirements as well as the buffers that they held in excess of required capital. A decline in required capital was made possible by changes in statutory rules relating to the prudential regulation of bank capital. The changes in rules provided banks with the option to determine regulatory capital requirements by assessing value-at-risk in the context of their own quantitative risk models, which they had developed for their own risk management. In particular, following the 1996 Amendment to the 
Basel Accord ("Basel I"), ${ }^{91}$ the great internationally active banking institutions were able to determine capital requirements for market risks on the basis of these internal models. The amount of capital they needed to hold against any given asset was thereby greatly reduced. ${ }^{92}$

The equity buffers that banks hold in excess of required capital have also been reduced. In the past, at least in Europe and Japan (before 1991), banks had consistently carried more equity than regulators required. Some of this equity was openly in their books, some of it was kept in the form of hidden reserves that they managed so in order to smooth their earnings reports. Since the early nineties, these buffers have been reduced to a bare minimum. To some extent, this is due to losses in the early nineties, from small business lending and real-estate lending in the second half of the eighties, eating these buffers up; moreover, the intensification of competition in the financial sector left little room to rebuild them. To some extent also, the reduction of buffers has been due to the conscious strategy choices of banks trying to "economize" on equity. The professionalization of risk management on the basis of quantitative risk modelling seemed to permit a reduction of buffers without seriously impairing the institution's viability. The possibility that the quantitative models might be seriously flawed was not given much attention. ${ }^{93}$

However, the relative decline in equity capital has made banking institutions more vulnerable to unforeseen shocks - or to the consequences of flaws in their risk modelling and risk management. Vulnerability appears at two levels. First, the small size of buffers of equity capital in excess of regulatory requirements means that banking institutions do not have much leeway to absorb a shock, but have to take corrective action almost immediately. Second, the small size of equity capital altogether means that, when a shock comes, solvency can quickly become an issue.

When the market prices of asset-backed securities began to drop in the second half of 2007 and fair value accounting required this drop to be acknowledged in the books, the institutions that held such securities had to react almost immediately. Some of them managed to obtain new equity. Others had to begin to deleverage, i.e., to reduce their lending or to sell assets in order to adapt the scale of their operations to their reduced equity. Given the need to satisfy regulatory requirements, they did not have much choice on whether they thought that market values of assets provided the right signals "for making long-term value-maximizing decisions". Because the equity capital that they held in excess of regulatory requirements did not suffice to

91 In public discussion, the regime change tends to be associated with the recent replacement of "Basel I" by "Basel II". In fact, the change of paradigm came already with the 1996 Amendment to "Basel I".

92 On this point, see the contribution of Zuberbühler to Hellwig and Staub (1996).

93 For expressions of this view, see Wuffli (1995) and Gumerlock's contribution to Hellwig and Staub (1996). 
absorb the shock, their behaviour was determined by an automatism under which asset price declines translated into write-offs and write-offs translated into asset sales. Through this automatism, the pressure on asset prices was increased further. From the perspective of the individual bank, the automatism was problematic because, for at least some of the assets in question, with book values far below fundamental values, it would have been better not to realize the book losses. From the perspective of the financial system as a whole, the automatism was problematic because it provided yet another element to the downward spiral.

By now, the book losses - or real losses - have become large enough to erode the solvency of important institutions. Of particular interest is the case of Fannie Mae and Freddie Mac, the government sponsored enterprises that had started the business of mortgage securitization. As mentioned above, these institutions had been securitizing prime, rather than subprime mortgages. However, they were severely undercapitalized. By the summer of 2008, their equity was eroded by losses, partly because the crisis began to reach prime, as well as subprime mortgages, partly because in 2007, under pressure from the US Congress, they had tried to support the market by buying subprime mortgage-backed securities which they subsequently had to write down.

Most recently, the failure of the United States to also bail out Lehman Brothers had a direct impact on banks and final investors worldwide that had deposited funds with Lehman Brothers. At least as importantly, it suggested that bailouts of banks could not be taken for granted, and, therefore, that it might be wiser not to lend any money to any bank. The result was yet another breakdown of interbank markets. Because, by this time, there was a sense that the difficulties affected the entire financial system and that it concerned the solvency, rather than the liquidity positions of banks, this breakdown was even more daunting than the one of August 2007. When a bank has a liquidity problem, the problem can be neutralized by central banks lending against collateral. When the bank has a solvency problem, the problem can only be neutralized by the finance minister and, ultimately, the tax payer. $^{94}$

\subsection{Systemic Effects of Prudential Regulation}

The preceding discussion of the role played by bank equity brings out a deleterious systemic effect of the currently existing regime of prudential regulation of banks through capital adequacy requirements. As currently practiced, this regime is highly procyclical, allowing banks to expand in goods times and forcing them to contract in bad times. Such behaviour of the bank reinforces

94 On the respective roles of central banks, bank supervisors, and finance ministers in a crisis, see the last section of Hellwig (2007). 
fluctuations in the rest of the financial and economic system. Over the past year, the feedback mechanisms that are thus created have been operating with a vengeance.

To explain these mechanisms, I go back to the distinction I made before between equity capital that is needed to fulfil the requirements of statutory regulation and equity capital that is held as a buffer, in excess of statutory capital requirements. Underlying this distinction is a paradox of banking regulation: Any position in the bank's balance sheet that serves as a buffer against unforeseen contingencies ceases to serve this buffer function when a regulator imposes a rule stipulating a minimum amount for this position. The paradox has been known for a long time from minimum reserve requirements: Deposits with the central bank or cash that are held to meet minimum reserve requirements are not providing the bank with a reserve that it can use when there is an unexpected shortfall of cash inflows. These funds only serve to meet the regulatory requirement. Similarly, equity capital that is held to meet capital adequacy requirements provides the bank with an imperfect sort of buffer against unforeseen losses. To be sure, such capital ensures that losses do not immediately make the bank insolvent. However, it does not give the bank a breathing space in which to adjust its strategy. This latter purpose is only served by equity buffers in excess of capital requirements.

Once equity buffers in excess of capital requirements are exhausted, any additional loss eats into the capital that is needed to meet the regulatory requirement. To avoid running afoul of the regulation, the bank must either obtain new equity capital, which, in a crisis situation, is not easily done, or it must adapt its holdings of risky assets to the reduced equity capital, i.e., it must sell marketable assets, withdraw deposits from other banking institutions, or reduce lending to its loan clients. All these actions have a negative impact on the rest of the financial and economic system.

The procyclical nature of the existing regime of capital adequacy regulation has always been a subject of criticism. In the past, this criticism had mainly been concerned with the behaviour of flow variables in the macroeconomy. A typical argument would be that a macroeconomic recession is reinforced by capital regulation because the downturn affects borrowers' debt service to banks, the worsening performance of debt reduces banks' profits and, hence, the rate at which they add to their equity and the capacity they have for new lending. ${ }^{95}$ This mechanism is said to have contributed to the credit crunch that affected the US economy around 1990.

The current crisis has shown that these early warnings about the effects of the existing regime of capital adequacy regulation were much too optimistic. Under fair value accounting, bank losses concern revaluations of assets, i.e., stock variables, not just the flows of debt service from borrowers. To avoid 
running afoul of capital adequacy regulation after such losses in stock variables, it is not enough to reduce the flow of new lending, but some adjustment is needed in the stocks of assets held by the bank. ${ }^{96}$ The effects that such an adjustment in stock variables has on the rest of the financial and economic system, holders of assets that the bank needs to sell, counterparties to deposits that the bank is withdrawing or to loans that it is rescinding, are much more dramatic than the effects of a credit crunch that is limited to new lending. The past year has provided ample evidence.

\subsection{Systemic Risk in the Crisis: An Interim Summary}

The preceding account can now be summarized as follows. When the downgrades of mortgage-backed securities by the rating agencies let the subprimemortgage financial crisis break out into the open in July and August 2007, market participants were surprised by the extent of the downgrading. They were also surprised by the extent of the liquidity and solvency problems that were associated with conduits and SIVs and the breakdown of these institutions as channels for holding asset-backed securities. Both these surprises induced a sense of panic, leading investors to position themselves defensively, without much willingness to contribute to making the needed adjustment as smooth as possible.

Since then, the interplay of market malfunctioning in the crisis, fair value accounting, insufficiency of bank capital, regulatory requirements and corrective actions of banks has involved the financial system in a downward spiral that has yet to come to an end. Government interventions may end up preventing the worst, though, at least for a while, political systems in European countries as well as the United States seem to have been bent on contributing to the downward spiral by having frequent and contentious discussions about interventions whose scope and credibility were not very transparent.

As yet, we have to see the repercussions of the defensive behaviour of financial institutions for the financing of the real sector of the economy. To the extent that firms in the real sector are unable to obtain financing for large investment projects or are unwilling to even apply for financing for such projects because they have doubts about the continued availability of funds as the project is being carried out, such repercussions are to be expected. The ensuing macroeconomic downturn will subject the financial system to additional stress. $^{97}$

96 This effect of combining capital adequacy regulation with mark-to-market accounting is pointed out in Blum and Hellwig (1996), however, without a full appreciation of the impact on the financial system.

97 In the assessment of losses from the crisis in the Global Financial Stability Report of October 2008 (International Monetary Fund 2008b), the difference between the total loss estimate of 1.4 trillion dollars and the estimate of 750 billion dollars from US residential 
These developments provide the answer to the question of the Bank for International Settlements, cited above, how the crisis in subprime mortgagebacked securities, such a small sector of global financial markets, could provoke such a worldwide dislocation. If it hadn't been for the systemic repercussions that I have described, the losses in residential mortgage-backed securities would not have reached the 500 billion dollars estimated by the International Monetary Fund, and even these 500 billion dollars would not have been able to cause a crisis of the dimensions that we are seeing.

In the theoretical literature on financial systems, systemic risk, i.e., the risk that problems at one institution endanger the rest of the financial system, is typically ascribed to one of three mechanisms: ${ }^{98}$

- Domino effects through contractual relations occur if one institution's going under requires other institutions to write down the contractual claims that they have on the failing institution.

- Domino effects through asset prices occur if the impaired institution has to liquidate assets, this liquidation depresses asset prices, and the decline in asset prices affects the solvency of all institutions that hold such assets.

- Information contagion effects occur if observations of difficulties at one institution induce investors to be worried about other institutions and to withdraw funding from them. Such worries arise if one suspects that the other institutions may have followed similar strategies or if one suspects that the other institutions may be threatened by domino effects, through contractual relations or through asset prices.

In the downturn that we have been experiencing, all three of these effects have been at work. The breakdowns of conduits and SIVs as well as some of the credit insurers and, most recently, the failure of Lehman Brothers exerted domino effects through contractual links on sponsors, clients, creditors, and, not least, the insurers of the risk that Lehman Brothers might default. ${ }^{99}$ The interplay of markets, fair value accounting, regulatory requirements, and corrective actions of banks with insufficient equity can be seen as a chain of

Footnote 97 continued

real-estate lending tries to take account of these further repercussions. Actually, this difference only comprises losses on other kinds of debt instruments, commercial asset-backed securities, corporate loans, and the like. It does not comprise, e.g., stock market losses, which, according to the World Federation of Exchanges, have amounted to some 15 trillion dollars worldwide from June 2007 to September 2008, 3 trillion dollars just on the New York Stock Exchange; see "domestic market capitalization" at http://www.world-exchanges.org/WFE/home. asp?menu $=395 \backslash \&$ nav $=$ ie.

98 Staub (1998a) and Hellwig (1998b) only refer to domino effects through contractual relations and to information contagion. The importance of dominos effects through asset prices is stressed by Schnabel and Shin (2004) and Allen and Carletti (2006, 2008).

99 The crisis of the large insurance company AIG, which followed almost immediately, was in large part due to their having provided such insurance. 
domino effects through asset prices. Finally, information contagion played a crucial role in shaping defensive retrenchment in interbank markets as well as asset markets.

Given this account, it is important to understand what went wrong. As mentioned in the introduction, public discussion of the crisis tends to focus on moral hazard and on the greed of bank managers. For the mortgage securitization that triggered the crisis, we have seen above that moral hazard in origination and moral hazard in securitization indeed played a role, driven by flawed incentives and flawed perceptions of risk. For the systemic repercussions of the initial crisis, the matter is less clear. In the following, I will argue that, here, we must distinguish between the contribution to systemic risk that came from excessive maturity transformation through conduits and SIVs and the contribution to systemic risk that came from the interplay of market malfunctioning, fair value accounting, and the insufficiency of bank equity.

\subsection{Excessive Maturity Transformation - Who is to Blame?}

As I see it, there is no excuse for the way in which certain banks used conduits and structured-investment vehicles in order to avoid capital requirements for holding asset-backed securities and to avail themselves of extra returns from maturity transformation. Hardly a risk in banking is as well known as the risk that is taken if one tries to earn money by using relatively cheap short-term funds to finance a longer commitment. Recent decades have provided many examples. The bankers involved must have known that a conduit with hardly any equity capital that issued commercial paper to finance the holding of long-term asset-backed securities was basically a time bomb waiting to explode. The question is why they engaged in this operation anyway.

One answer to this question is provided by Table 2 above: From 2002 to 2004, yield curves were very steep. Money market rates - and commercial paper rates! - were significantly below $2 \%$, ten-year treasury rates between 4 and $5 \%$, ordinary mortgage rates around $6 \%$. The margin between the interest rates on ordinary mortgages and the interest rates on short-term securities was on the order of four to five percentage points. Such a margin provided an enormous temptation to "play the yield curve", i.e. to borrow short in order to lend long. For many institutions, this temptation was too much to resist. Yield mania and yield panic blinded them to associated risks in their refinancing choices as well as in their investments in asset-backed securities.

In this context, the monetary policy of the United States must take some of the blame. The low money market rates in 2002-2004 were largely the result of the Federal Reserve Bank's trying to counteract the macroeconomic effects of the stock market downturn that had begun in March 2000 and 
accelerated after September 11, 2001. Given the downturn that was occurring, the Federal Reserve Bank's activism may have been understandable, especially in view of the fact that 2004 was going to be an election year. Already twice before under the Chairmanship of Alan Greenspan, the Federal Reserve Bank had engaged in such activism, first, by flooding the markets with liquidity after the 1987 crash, and, second, by lowering money market rates in 1990 when US commercial banks appeared to be on the threshold of a major crisis; ${ }^{100}$ from 1990 to 1994 , monetary policy enabled the commercial banks to rebuild their equity, earning record profits one quarter after the other by playing the yield curve.

A closer look at both these episodes would have shown that such activism was not without risks: There are good reasons to believe that the quandary of US commercial banks in 1990 had been caused by a combination of excessive lending in 1988, when monetary policy was extremely easy, and the interest rate increase in 1989, when recognition of the inflation that had been fuelled in 1988 induced the central bank to step on the brakes. There are also good reasons to believe that the financial turbulence that followed the relatively small interest hike in 1994 was largely due to the interest rate vulnerability of institutions that had been playing the yield curve. Thus, in both episodes, a phase of monetary ease seems to have induced behaviour that made financial institutions vulnerable to the effects of monetary tightening. However, this lesson from these earlier episodes seems to have been overlooked. ${ }^{101}$

To some extent, the willingness of banking institutions to engage in maturity transformation through conduits and SIVs may also have been due to their underestimating their own commitments in these ventures. After all, they were separate legal entities, with assets and liabilities that were kept separate from the sponsoring institutions' balance sheets. Commitments to provide liquidity in case of need were not put into balance sheets either; presumably, such commitments did not have to be put into the accounts if the sponsoring bank's management considered it more likely than not that the commitment would not be called upon. In the crisis, of course, the commitments were called upon, and some banks found that, for the sake of their reputations, it was necessary to accept liabilities of their conduits and SIVs even beyond their own legal obligations.

100 On this crisis, see Bernanke and Lown (1991), Boyd and Gertler (1994).

101 If the turnaround in US residential real-estate markets is seen as being induced by the tightening of monetary policy in 2005 and 2006 (see Table 2), then at least the onset of the current crisis can be said to have followed the same pattern as the earlier crises. However, it seems hardly appropriate to blame the crisis on tight monetary policy in 2005 and 2006; the development that I have described above seems like a bubble that was bound to burst sometime. As for Japan in 1991, the tightening of monetary policy merely provided the pinprick. 
As a naïve academic, I have been wondering why commitments to provide liquidity in case of need would not have fallen under the prohibition of excessively large loans to single clients, at least for those institutions where such prohibitions are an integral part of prudential regulation. In Germany, for instance, the law stipulates that loans to a single client must not exceed $25 \%$ of equity capital. A loan of more than four times the equity capital is not compatible with this regulation, yet, this is what Industriekreditbank and Sächsische Landesbank promised to provide to their conduits in case of needs. A lawyer might argue that a promise to provide such a loan is not the same as the loan itself, that the promise has been a conditional one, that it has been split into multiple smaller promises, and that all these considerations make a difference in law. In substance, these considerations do not make a difference, and, to me, these banks' promises of liquidity assistance to their conduits smack of illegality.

In the end, of course, conduits and SIVs turned out not to be so independent after all, but had to be taken onto the sponsoring banks' balance sheets. This outcome suggests that it would have been better to treat them as integrated subsidiaries from the very beginning, i.e., to enter their assets and liabilities into the sponsoring banks' balance sheets. At the very least, this would have improved transparency about their doings. It would also have forced the sponsoring banks to put equity capital behind these institutions' holdings of asset-backed securities. This might have slowed their growth and diminished the danger they posed for the system.

\subsection{Excessive Confidence in Quantitative Models as a Basis for Risk Management}

For institutions that were not sponsoring conduits or SIVs, the assessment of behaviour is less clearcut. To be sure, with hindsight, it is clear that some of their strategies were disastrous, for themselves as well as the financial system as a whole. However, hindsight is not a good guide. For each decision, there is a risk that it may turn out badly. If this risk is realized, i.e., if the decision has indeed turned out badly, one cannot automatically infer that the decision should not have been taken. The question is whether there are reasons to believe that the decision was flawed from an ex ante perspective, without the benefit of hindsight.

In thinking about this question, it is important to appreciate that, before July 2007, nobody knew about the extent of the systemic risk that was created by the activities of conduits and SIVs. Given the lack of transparency about exposure to systemic risk from these institutions, it is difficult to blame the portfolio managers and risk managers at institutions like UBS for not having taken this risk into account. One might as well blame the architect of the 
World Trade Center for not having taken the risk into account that kerosenefilled airplanes might be flown into the building.

However, risk managers, risk controllers, and, most importantly, top management at institutions like UBS can be faulted for not having taken account of the possibility that there might be risks that they had failed to consider. They relied on the quantitative risk models that they had developed and believed in their ability to control risks on the basis of these models. Their exposure to systemic risks from conduits and SIVs had not been incorporated into the models - and could not have been incorporated because they did not have the requisite information. However, as a matter of common experience, one might have reflected that quantitative risk models are necessarily imperfect and, therefore, that some provision should be made for possible flaws in risk modelling.

The development and use of quantitative models since the eighties has provided tremendous gains in the quality of risk assessment, risk management, and risk control of financial institutions. Most importantly, these models have contributed to a much better understanding of what the risk exposure of banks really is. Before the advent of quantitative risk modelling, risks in banking were not well understood, and this was one reason for the financial crises of the eighties and nineties. The de facto insolvency of a significant part of the savings and loans industry in the United States in the early eighties had resulted from a failure to understand the risk implications of the maturity mismatch in these institutions' balance sheets. The banking crises of many countries in the late eighties and early nineties had resulted from a failure to properly recognize risks and correlations of risks in real-estate and small-business lending. In both instances, the flaws were not even in the measurement of risks, but in their conceptualization. The relevant questions, namely what could these lending activities and what could correlated risks in these activities mean for the bank as a whole, had not even been asked. The use of quantitative risk modelling as a basis for a comprehensive system of risk control ensured that these questions were at least asked and that answers corresponded to the state of the art in risk analysis. ${ }^{102}$

This being said, one must recognize that the reliability of a quantitative risk model is limited. Statistical inference from empirical data presumes that, at some level, the data can be interpreted as instances of experiments with common underlying parameters and independent disturbances; reliance on this inference for decision making presumes that the common underlying parameters will still be relevant in the future. In practice, however, the data

102 The account in Staub (1998a) gives some indication of how revolutionary the change in bank management was. See also Schütz (1998). 
that can be used as inputs for quantitative risk models do not exhibit the stationarity and independence properties that the statistical theory assumes. ${ }^{103}$

In particular, correlations are subject to change over time. Even with the best of data, correlations are therefore hard to ascertain empirically, and risk models are notoriously unreliable about correlations. ${ }^{104}$ Yet the importance of correlations is shown very clearly by the account that was given in Section 3 of the common dependence of mortgage-backed securities on the factors that were underlying the development of US real-estate markets. The impact of systemic risk in the crisis, provoking a downward spiral in many markets at once, provides another illustration. The quantitative risk models had not taken these systemic risks into account. Nor could they have done so, given the lack of relevant information and data.

When I first raised the issue of exposure to systemic risk at a conference in Basel in 1995, the discussant, Peter Wuffli, who at the time was Chief Financial Officer of Swiss Bank Corporation, answered squarely that systemic risk must be dealt with by the central bank because the individual banking institution was unable to do so. ${ }^{105}$ At the time, I thought that this response was an instance of moral hazard induced by the presence of a lender of the last resort. However, after years of thinking about the problem, I have come to accept the assessment that, given the complexity and the fluidity of the network of interbank relations, there is no way in which the quantitative risk model of an individual bank could satisfactorily take account of the institution's exposure to systemic risk. This being said, I wonder why the quantitative risk model of an individual bank should be accepted as the sole basis for determining the amount of equity capital that the bank must have to meet regulatory requirements.

This brings me back to the observation that the incidence of systemic risk in the crisis has been exacerbated by an insufficiency of equity capital in banks. As the system of risk management on the basis of quantitative risk models was being implemented, banks were becoming more conscious of the desirability of "economizing" on equity capital and of the possibility of using the quantitative risk models for this purpose. Some of the economizing on equity capital involved improvements in the attribution of equity capital to different activities, based on improvements in the awareness and measurement of these activities' risks. Some of the economizing on equity capital led to the relative decline in equity that I referred to above as one of the elements shaping the dynamics of the downward spiral of the financial system since August 2007. One may assume that the loss of resilience

103 For a detailed discussion of why it is difficult to assess the quality of a quantitative risk model, see my contribution to Hellwig and Staub (1996).

104 On this point, see again Duffie (2007).

105 See Hellwig (1995) and Wuffli (1995). 
that was caused by the reduction in equity capital was to some extent outweighed by the improvements in the quality of risk management and risk control. However, there may also have been something akin to the effect that the instalment of seat belts or anti-blocking systems in cars induces people to drive more daringly. ${ }^{106}$ A greater feeling of protection from harm or a stronger sense of being able to maintain control may induce people to take greater risks. Professional enthusiasm about the new risk control technology may give rise to overconfidence or even hubris.

I appreciate that, in the assessment of insufficiency of equity capital, as in other matters, it is important to avoid succumbing to hindsight bias. Ex post, it is clear that equity capital was insufficient, but then, as the crisis has developed, one may suppose that, within the range that may realistically be considered, any amount of equity would have proved insufficient. However, one may also suppose that, if the banks had had greater equity buffers, they would have had greater leeway in determining their reactions to the crisis and the downward spiral might have gone less far than it has.

At this point, I come back to the discussion of biases in bank governance in Section 3.6 above. As discussed there, discourse inside the banks and in relations between the banks and the representatives of "market discipline" seems to have focussed on yield, without questioning the implications for the institution's exposure to risk. The ability to control risk through model-based risk management was taken for granted, to be handled as a matter of routine. In the case of the Swiss bank UBS, this attitude provided the investment banking branch with the means to prevent any comprehensive risk assessment of their activities by Senior Group Management until the summer of 2007. The very same attitude seems to have been responsible for the extent to which such institutions were "economizing" on equity. 107

Above, I have suggested that the focus on yield at the expense of risk may be reinforced by governance mechanisms that rely on "market discipline" in the name of "shareholder value", and that the ease of measuring returns and of communicating about returns as opposed to measuring risks and communicating about risks introduces a bias in favour of strategies that involve

106 The classic reference on this point is Peltzman (1975).

107 For UBS and Crédit Suisse, the Financial Stability Department of the Swiss National Bank has raised concerns about the insufficiency of equity capital since at least 2001 and had put forward proposals to supplement existing capital regulation by a leverage ratio which would install an overall floor for the equity ratio; see Bichsel and Blum (2001, 2005), Blum (2008). Prior to the crisis, these proposals met with the response that the size of the balance sheet was not a good indicator of risk because, for many assets and liabilities, returns and obligations were so highly correlated that the net impact of these positions on the risk of the bank was negligible and hardly any equity was needed to cushion this risk. The notion that there might be limits to the ability of quantitative models to assess the "negligibility" of risks, which underlay the Swiss National Bank's concerns, does not seem to have entered the banks' decision making. 
greater risk taking. All these arguments are relevant for assessing strategies of "economizing" on equity as well as strategies of investing in high-yield securities.

Even if risks to shareholders are properly taken into account, a system of "market discipline" in the name of "shareholder value" is unlikely to also take into account the risk implications of the bank's strategy choice for its creditors and for the financial system as a whole. It might do so if excessive risk taking at the expense of lenders would lead to immediate withdrawals of funds and would thereby harm the profitability of the institution. ${ }^{108}$ However, before the crisis broke out into the open in August 2007, there was little evidence of such "market discipline" from the creditors of banks, let alone such "market discipline" from shareholders fearing such creditor reactions.

\subsection{Regulatory Capture}

In principle, the risk implications of banks' strategic choices for their creditors and for the financial system as a whole provide the main rationale for statutory prudential regulation of banks. As mentioned above, the relative decline in the equity capital of banks that we have seen since the nineties has partly been due to banks availing themselves of the option provided by the 1996 Amendment to the Basel Accord of determining regulatory capital for market risks on the basis of their own quantitative risk models, rather than the crude ratios that had been used before and that were still being used in the so-called standard approach. The criticism that there was an excessive reliance on quantitative risk models, must therefore be directed at bank regulators and supervisors as well as bank managers.

Acceptance by the regulators of the model-based approach to determining regulatory capital requirements was the result of intense lobbying by prominent banking institutions in the first half of the nineties. In 1993, the Basel Committee on Banking Supervision issued a draft proposal for the determination of bank capital requirements for market risks on the basis of crude ratios of the sort that was used for credit risks under the 1988 Basel Accord ("Basel I"). The banking industry responded with intensive criticism, arguing that such regulation would represent a step back from the very sophisticated risk management procedures that they themselves had started to implement on the basis of quantitative models. Two years later, in 1995, a modified proposal was presented, which gave banks the option to use a model-based approach, rather than the approach that had been originally proposed (now called the standard approach). Another eight months later, this modified approach was codified in the 1996 Amendment to the Basel Accord. 
The banking industry was certainly right in claiming that, as a way of dealing with market risks, the standard approach was clumsy and would have represented a step back from the sophisticated risk management methods that they were already using. The banking industry was also right in suggesting that they knew more about risk management than the regulators. However, in this discussion, the notion that there is a difference between private interests and the public interest in risk management and risk control of a bank seems to have been lost. I think of this process as regulatory capture by sophistication. ${ }^{109}$

The question of how to protect the public interest against possible flaws in the quantitative risk modelling of banks does not seem to have been given much attention. ${ }^{110}$ The quality of professional risk modelling in sophisticated banking institutions seems to have been taken for granted. The possibility that the model designers might simply fail to properly appreciate an important risk factor does not seem to have been considered. In the end, this possibility materialized when, e.g., risk modellers at UBS neglected the role of residential real-estate prices in the United States as a common factor underlying all mortgage-backed securities. Nor was any attention paid to the possibility that the bank's quantitative risk model might be inherently incapable of capturing exposures to systemic risk that result from the activities of other institutions about which one is not informed, from excessive maturity transformation by SIVs to the counterparty risks of monoline insurers to whom one has transferred the credit risks of mortgage-backed securities.

The capture of regulators by the industry was facilitated by the political constellation: A body of representatives from regulatory authorities and central banks of the G-10 countries, the Basel Committee on Banking Supervision was developing principles aiming at international co-ordination and harmonization of banking regulation when the sector itself was undergoing tremendous structural change, driven by revolutions in information processing, communications and risk management technologies and promising to open great new fields of business activity. For the participants from different countries, these negotiations involved the future competitive positions

109 For a bank supervisor's expression of strong unease about this process, its outcome, and its implications for the amount of capital that banks would be required to have, see the contribution of Zuberbühler to Hellwig and Staub (1996).

110 Hellwig and Staub (1996) documents a panel discussion with members of the regulatory community and members of the banking community on these issues. My own contribution pointed out that (i) the Supervisory Framework for Backtesting of Models that the Basel Committee had provided did "not seem to recognize the fundamental conceptual difficulties of doing statistical inference in a nonstationary world" and (ii) it was incongruous to "believe in the integrity of senior (bank) management in its dealing with risk control if at the same time we believe that senior management is not to be trusted to manage risks properly unless it is subjected to a capital adequacy requirement". 
of "their" home institutions as well as the safety and soundness of globally operating banks. In particular, for countries with banking institutions at the forefront of change, most prominently the United States, the introduction of the option to rely on a model-based approach seemed like a chance to have "their" institutions benefit from their advantages in global competition in newly developing markets. Even if the bank regulators involved in the negotiations may have had their doubts about the change, the political environments from which they came provided them with little leeway to express these doubts, let alone have them prevail in the international deliberations.

A similar logic may have been at work in the late nineties when Federal Reserve Board Chairman Greenspan, Treasury Secretary Rubin, and Securities and Exchange Commission Chairman Levitt, all three of them with strong ties to the investment banking community, used their influence to stop attempts to bring derivatives trading into the domain of statutory regulation, if only to impose transparency about trades, positions, and participating parties. More transparency here might also have meant transparency about conduits and SIVs.

\subsection{Conceptual Weakness of Regulatory Thinking}

The regulatory community's vulnerability to capture is partly explained by the lack of a coherent conceptual framework for thinking about what prudential regulation is doing. When asked why a capital adequacy requirement is useful, a typical bank regulator will answer that it promotes the safety and soundness of banks, the ultimate objective of all banking regulation. When asked how a capital adequacy requirement contributes to promoting the safety and soundness of banks, he will argue that a more highly capitalized bank is less likely to go bankrupt. When asked whether this argument wouldn't call for a capital requirement of $100 \%$, i.e., an all-equity-financed bank, he will tend to agree and then talk about the need to take account of the fact that bankers consider equity capital to be very costly. This intellectual stance does not provide a good basis from which to argue with bankers bent on reducing their capital requirements.

In the past, capital requirements had not been at the centre of the stage in banking regulation. Banking regulation had relied on a mixture of asset allocation rules and deposit rate regulation. These rules had been developed in the thirties, after the Great Depression, and they worked until the seventies, in a period when banking rarely crossed national borders and it was easy to reduce or even eliminate competition in banking by national regulation and/or cartel agreements. However, in the seventies and eighties, most of these rules were dismantled because, as the financial sector underwent structural change, they were seen as being dysfunctional, weakening the position 
of domestic banks in competition with other banks internationally and in competition with non-bank intermediaries, and weakening their ability to cope with increased risk in a world of wide fluctuations in interest rates and exchange rates. ${ }^{111}$

Capital regulation began to take centre stage in the mid eighties, when bank regulators from the G-10 countries got together to create a framework for prudential regulation in the face of increasing globalization of financial activities. Acceptance of the home-country principle, leaving all supervision to the regulatory authorities of the bank's home country with no additional supervision by authorities of other countries in which the bank might be active, was coupled with an agreement on harmonized principles for such regulation. ${ }^{112}$ The result, as codified in the Basel Accord of 1988, focussed on capital requirements, perhaps because the experience of the savings and loans crisis had sensitized the American participants to the dangers of undercapitalized, or even negatively capitalized, institutions "gambling for resurrection", perhaps also because, by contrast to asset allocation rules and deposit rate regulation, capital requirements were the one instrument where harmonization across countries was not obviously nonsensical. ${ }^{113}$ However, there had not been any theoretical or empirical work on the effects of capital requirements on the financial system and the overall economy, let alone the differences between the effects of different rules for computing capital requirements. ${ }^{114}$

Even now, twenty years after the first Basel Accord, the intellectual foundations of capital regulation are weak; the weakness concerns the new Basel Accord ("Basel II") as well as the original one. Some of the flaws in regulatory thinking have contributed to the downward spiral in the crisis that we have experienced.

111 On this development, see Baltensperger and Dermine (1987), Englund (1990), Mélitz (1990), Vives (1990), OECD (1992).

112 For an example of regulatory thinking at the time, see Carosio (1990).

113 However, even here, one may question whether, e.g., real-estate loans in different countries should be treated as being equally risky; see Schaefer (1990).

114 For criticisms of the lack of theoretical or empirical foundations, see King (1990) and Schaefer (1990). Both point out that neither the regulatory community nor the academic community have any framework for assessing the bankers' claim that equity capital is very costly: Are these private costs to bank managers that have to go to the market to get additional equity capital? Or are these social costs because additional equity for a bank means less equity for other purposes? According to the Modigliani-Miller Theorem of corporate finance, it is not clear that there would be any social costs. Hellwig (1996) compares "the speed with which the regulatory community moved from the April 1993 and April 1995 proposals to the actual Amendment to the Capital Accord to Incorporate Market Risks of January 1996 to the time and expenses it takes for a private company to get a new drug approved for sale" and notes that "both the 1988 Accord and the 1996 Amendment to the 1988 Accord were enacted with hardly any evidence about the economic effects of capital requirements for banks." 
In my view, prudential regulation under the Basel Accords has the following major shortcomings:

- The purpose of capital regulation is unclear.

- The dynamics of capital regulation are neglected.

- The systemic dimension of capital regulation is ignored.

In the following, I will explain these points as well as their significance in the current crisis.

The purpose of capital regulation is unclear: In the regulatory and academic literatures, I see at least three rationales for capital regulation: ${ }^{115}$

- Equity capital provides a buffer against insolvency.

- Equity capital affects incentives for risk taking. ${ }^{116}$

- Capital regulation provides room for intervention by the supervisor at a time when the bank is not yet subjected to insolvency proceedings. ${ }^{117}$

One might consider that the difference does not matter if, in fact, capital regulation can serve all three purposes. However, the rule for determining required capital will depend on which of the three purposes one is thinking of. If one is thinking of equity capital as a buffer against insolvency risk, one is concerned about the total risk to which the institution is subjected. The risk weights of different assets should then be tied to the total contribution that each asset makes to the institution's risk. If one is thinking of equity capital as an incentive device, one must be concerned about incentive effects at the margin and attune the risk weights of different assets to the marginal impact of increases in the different asset positions on the institution's risk. With correlations of returns on the different assets, there is no reason why risk weights attuned to marginal risk contributions should coincide with risk weights attuned to total risk contributions. Finally, if capital requirements are there to provide room for supervisory intervention before the onset of bankruptcy, there is no reason why risk weights of assets should matter at all. In this case, it seems more important to make sure that the intervention threshold cannot be manipulated and to have a plan for how to intervene when the threshold is reached. To the extent that different assets should carry different weights at all, the different weights should probably be attuned to differences in marketability of these assets, because these differences affect the difficulty

115 For evidence of the heterogeneity of rationales, see the discussion documented in Blattner (1995).

116 Formal models to this effects have been provided by Rochet (1992), Dewatripont and Tirole (1994).

117 This was the rationale for the system of graduated responses stipulated by the Federal Deposit Insurance Corporation Improvement Act (FDICIA) of 1991 in the United States. 
of the corrective intervention in the crisis. ${ }^{118}$ There is thus a potential for conflict between the different purposes of capital regulation. As far as I know, this conflict has never been addressed, let alone resolved.

The dynamics of capital regulation are neglected: ${ }^{119}$ Explicitly or implicitly, most thinking about the impact of capital regulation on risk in banking comes from a two-period framework. In this framework, there is a first period in which the bank chooses its liabilities, equity capital, deposits, subordinated debt, etc., and its assets; then, in the second period, returns are earned and distributed to the different financiers. Little attention has been paid to the fact that banks do not operate in a two-period world and that, in the real world, there are repeated refinancing choices and portfolio choices to be made. In the real world, one must think not only about the impact of the initial imposition of capital requirements, but also about the impact of imposing capital requirements in subsequent periods.

For this purpose, it is not enough to think about "tomorrow" as a new "period one" in the two-period framework of analysis. To see this, observe, first, that the bank's equity position "tomorrow" depends on the fate of its investments "today", the assessed values of long-term investments that still have some time to go, as well as actual returns from short-term investments that have already matured. Second, as of "tomorrow", the long-term investments from today may not be liquid. Such illiquidity affects the bank's ability to adjust its asset portfolio to the requirements of capital regulation "tomorrow". Third, the bank managers' anticipation "today" of the impact of capital requirements on its business opportunities "tomorrow" may have incentive effects on the bank's portfolio choice "today". 120

Given these additional concerns that arise in a world with repeated, ongoing financing choices and portfolio choices of banks, any mechanical extension of results and recommendations from a two-period framework to such a world with more than two periods is questionable, if not harmful. For instance, a policy of enforcing capital requirements mechanically in each period can contribute to a bank's insolvency risk if, following a market downturn, such a policy forces the bank to liquidate assets at a time when cur-

118 Remarkably, this question has not been given much attention. Even in the United States, supervisors have shied away from filling the provisions of FDICIA with substance.

119 For an extensive discussion of this point, see Hellwig (1995).

120 Blum (1999) presents a model showing that, if one considers the incentive effects of tomorrow's capital requirements on today's behaviour, the requirements can be counterproductive, in the sense that they lead to more risk taking, rather than less. If bank managers appreciate that every extra dollar of profits that they earn on "today's" investment enhances their loan capacity "tomorrow" by 12.5 dollars, they may be inclined to choose a strategy "today" which provides them with big opportunities of exploiting this additional leverage if it succeeds and leaves the regulators with a mess if it fails. 
rent market prices are significantly below the expected present value of future returns.

In view of these additional concerns, the key question for capital regulation in a world with repeated, ongoing refinancing and portfolio choices of banks should be how the bank's assets and liabilities are to be adjusted over time when losses have caused a drop in equity capital. Neglect of this question - and of the concerns that underlie it - has been responsible for the detrimental effects of regulation that were discussed in Section 4.6 above, in particular, the interplay of fair value accounting, capital regulation, and the induced corrective actions of banks in the downward spiral.

The systemic dimension of capital regulation is ignored: When asked why statutory regulation is needed to provide for the safety and soundness of banks, i.e., why the safety and soundness of banks cannot be left to the contractual relations between banks and their creditors, a bank supervisor will refer to the need to forestall systemic risk, as well as the need for investor protection. In the actual regulation, however, systemic risk plays no role. There seems to be a view that solvency regulation and supervision of all institutions, one by one, is enough to forestall systemic risk. I consider this view to be mistaken and dangerous.

To be sure, if the regulators are able to prevent each and every banking institution from going under, there is no systemic risk. However, I don't see the present system of banking regulation as being able to do this; moreover, I don't see any realistic prospect for achieving this aim by improvements in regulation and supervision.

Because of systemic interdependence, the individual bank's risk exposure cannot be ascertained by just looking at the bank's assets and liabilities, on balance sheet and off balance sheet. If the bank's asset position involves a certain risk and the bank has hedged this risk by contracting with a third party, the effectiveness of the hedge depends on the third party's ability to fulfil its obligations when needed. If the risk in question is of macroeconomic dimension, an interest rate risk, exchange rate risk, or a housing-price risk, the counterparty's ability to fulfil its obligation depends on how many similar contracts it has concluded with other market participants. If risk correlations across contracts are such that the counterparty to the hedge must deliver on many of them at the same time, this in itself may destroy the counterparty's viability. The difficulties that the monoline insurers of credit risk in mortgage-backed securities have had over the past year - or the more recent crisis of AIG - provide a telling example of the problem. To assess whether the risk in the bank's asset position is really neutralized by the hedge with the third party, the bank's supervisor would have to be informed about the counterparty credit risk of the hedge contract and about the correlation of this counterparty credit risk with the risk against which the bank is hedging. To ascertain the counterparty credit risk and its correlation with the risk 
against which the bank is hedging, the supervisor would have to know the total exposure of the counterparty, across all contracts, to the risk that it is providing the hedge for. ${ }^{121}$

Similarly, to know the bank's exposure to systemic risk from the effects of other market participants' difficulties on asset markets and asset prices, the supervisor would have to know the balance sheets of the other market participants. On this point, a telling example is provided by the exposure of banks all over the world to the systemic risks induced by the excessive maturity transformation of conduits and SIVs, which nobody had appreciated prior to August 2007. If the positions of other market participants are not known, there is no way the supervisor can correctly assess the bank's exposure to such systemic risk just by looking at the bank's balance sheet.

In a sense, the view that a supervisor can assess the bank's solvency risks just by looking at the bank's assets and liabilities, on balance sheet and off balance sheet, is just as much the result of overconfidence, a neglect of the possibility that there might be things that one has failed to consider, as the view that a quantitative risk model provides a fully accurate assessment of the bank's risk position.

A member of the regulatory community might respond that, if the information about systemic risks to which the bank is exposed is not available, then there is nothing one can do about the problem. Here, as for the individual bank, I would respond that, at the very least, there should be an awareness of the issue, and this awareness should play a role in regulatory thinking, e.g., make for some scepticism concerning an all-out reliance on the bank's own risk models. I would also respond that, once one begins to appreciate that there is a problem, one may actually begin to think about possible sources for the requisite information. For instance, one might think about aggregating the financial reports of different participants in the financial system, or in one part of the financial system, in order to obtain a view as to what the aggregate risk position of the group in question is. ${ }^{122}$ If such an exercise had been performed on conduits and SIVs,...

A second issue concerns the systemic implications of regulatory intervention when an institution is in difficulties. This complements the concern, raised above, that the mechanical imposition of capital requirements may

121 A commentator has suggested that the problems of counterparty credit risk and its correlations with underlying macro risks are mitigated if the counterparties themselves are subject to supervision ensuring their viability. To the extent that the "if" in this statement is valid, this is true. However, the crisis shows that, in the presence of macro shocks affecting the entire financial system or of a macro shock that the financial system is generating all on its own, there is little assurance that supervision of the counterparties will ensure their viability. Indeed, if one looks at the various banking crises of the nineties, one finds that regulatory requirements had often been overfulfilled - until the crisis broke.

122 The basic idea is developed in Hellwig (1994b). 
increase the bank's insolvency risk by forcing it to sell assets in an illiquid and panicky market in which these assets are undervalued. Besides the negative effects on the bank itself, such an intervention also has negative effects on the asset markets and thereby on other market participants. At this point in my discussion, I hardly need to add that such negative effects of corrective actions of banks have played a significant role in the crisis.

\section{TOWARDS REGULATORY REFORM}

The crisis has given rise to many calls for regulatory reform. Unfortunately, many of these calls, including calls from politicians in positions of responsibility, are little more than spontaneous reactions to the observation that something has gone wrong. If something has gone wrong, it must be because there has been too little regulation and too little supervision. The question what has gone wrong and what kind of regulatory reform is needed is rarely addressed. The notion that the regulation we currently have may actually have exacerbated the crisis is not even considered. Many statesmen and politicians seem to be using the call for regulation to forestall such crises in the future as an opportunity to promote their pet projects, just as, in 2002, Iraq was made out to be the key to $9 / 11$.

This is not the place to go into the subject of regulatory reform in any detail. I will merely draw some conclusions from the analysis that I have presented.

\subsection{The Originate-and-Distribute Model of Mortgage Securitization}

Populist propaganda in Europe is suggesting that, if only European banks had avoided those junk mortgages in the United States, they would not have run into trouble. I consider this propaganda to be dangerous. From experience, we know that excessive real-estate speculation can be a problem in any country. From the late eighties and early nineties, we have examples from Sweden, Switzerland, France, Germany, Japan... In each case, lack of diversification meant that the speculation ended up having significant negative effects on originating banks and the domestic financial system. These effects could have been much reduced if the mortgages in question had been securitized and the risks shared internationally.

In thinking about the reform of mortgage securitization, it is therefore important not to throw out the baby with the bathwater. From the above analysis, it is fairly clear what needs to be done. Rules concerning liability of originators and/or securitizers must be introduced or strengthened. For example, it might make sense to require originators to retain an equity portion on each mortgage they transfer to a securitizer. 
It is probably sensible to prohibit the higher stages of securitization (MBS CDOs, MBS $\mathrm{CDO}^{2} \mathrm{~s}$, etc.). However, I see little prospect of these securities returning anyway. More importantly, it might make sense to have some system of oversight which examines whether newly created securities provide effective improvements to the scope for reallocating risks and sharing risks through markets or whether these securities are just there to circumvent statutory regulation of risk taking by insurance companies and the like.

The role of rating agencies needs to be reconsidered. To eliminate conflicts of interest, there should be a rule banning an agency from rating a security issued by an entity for which the agency itself or one of its subsidiaries has provided consulting services.

\subsection{Rethinking the Role of Prudential Regulation}

The performance of regulators and supervisors before and in the crisis has been marred by a lack of information about the extent to which the institutions they were supervising were exposed to systemic risk. This lack of information was in part due to the fact that important players, such as conduits, SIVs and hedge funds, were unregulated and did not even have to provide information about their positions. Because the information was not available, nobody appreciated the systemic risks in these institutions' positions. Such lack of transparency is unconscionable.

The fact that important players were not regulated stems from a view that the main task of prudential regulation is to protect investors and that such protection is only needed for small unsophisticated investors who find it difficult to protect themselves in the jungle of the financial system. For financial institutions like hedge funds, and presumably also conduits and SIVs, such concerns did not seem to justify a need for regulation; these institutions' investors were deemed to be large enough and sophisticated enough to fend for themselves. ${ }^{123}$

However, the events of August 2007 show that it is not enough to think about investor protection. Prudential regulation should also be concerned with the protection of the financial system. The financial system as a whole and the different markets that compose it should be protected from the kind of surprise that was experienced then. For this purpose, prudential regulation should be extended to all major participants in this system.

I am not proposing that all participants should be subject to the same set of rules. Indeed, I will argue below that rules should be differentiated in order to take account of differences in the roles and differences in the liability structures of different participants. However, all participants above a certain

123 Whether a fifty-million dollar investor in a three-billion dollar hedge fund is really important enough to fend for himself, is an open question. 
size should be required to provide the supervisory authorities with information about their positions so that the supervisory authorities can obtain some transparency about the system's risk exposure. The reason for imposing such a requirement is not to protect investors, but to protect the system of markets in which these institutions are active and the counterparties of these institutions in these markets.

The same reasoning suggests that distinctions between on-balance-sheet and off-balance-sheet positions of banks and other financial institutions should be abolished or at least reduced to a bare minimum. One suspects that regulatory acceptance of such distinctions until now may have had more to do with political lobbying and regulatory capture than with any substantive argument about differences in risk exposure.

The regulators and supervisors themselves should begin to think about the safety and soundness of the financial system as well as the safety and soundness of individual institutions. Given their tradition, this will not be easy. From a legal perspective, regulatory intervention is always based on rules that govern the relation between the regulator and the individual institution. If regulatory intervention is to be based on concerns about the safety and soundness of the financial system as well as the safety and soundness of the individual institution, these rules must be changed. As yet, however, we have no idea how systemic concerns can be introduced into the rules governing the bilateral relation between the regulator and the individual financial institution.

However, some steps in the desired direction should be easy:

- Regulators and supervisors should develop a framework for processing the information that they obtain from individual institutions so as to provide an overview over the overall risk exposure of the financial system, as well as certain subsets of financial institutions with similar roles and similar liability structures. For this purpose, they will need to co-operate internationally, perhaps even to overcome the sectoral fragmentation of prudential regulation and supervision in the United States. ${ }^{124}$

- The regulation and supervision of different types of institutions should be tailored to their specific positions in the financial system. A case in point is provided by the regulation of insurance companies. As mentioned in

124 One commentator has suggested that this suggestion is at odds with the criticism, expressed elsewhere in this paper, of excessive reliance on the risk models that are currently in use. I fully appreciate that the attempt to obtain a quantitative view of system risk exposure is even more ambitious than the attempt to measure the risk exposure of the individual bank. However, the point of my criticism of banks' risk models is not that these models are useless, but that any use that is being made should be tempered by an awareness of their potential failings. Having such models and using them with a grain of scepticism is certainly better than not having them at all. The same is true for the assessment of system risk exposure. 
Section 2 above, life insurers, with a long horizon on the liabilities side of their balance sheets, would be ideal holders of long-term securities associated with real-estate. One reason why they have not done so to such a large extent - and one reason why, in the crisis, they have not much been able to step in and profit from the discrepancy between expected present values and market prices - is that they have also been using fair value accounting. Indeed, the banking lobby, furious at insurers competing with banks in derivatives markets, has been militating for the introduction of capital regulation of insurers on roughly the same lines as banks. Homogenization of the regulation of different institutions may seem like a good idea for a banker who wants to eliminate competition, but comes at a great cost for the financial system because homogenization of participants reduces its resilience. Given that the liabilities of life insurers and banks have different maturities and different risk profiles, there is actually no substantive reason for this homogenization of regulation.

- Systemic thinking should be used in assessing risk exposures of individual institutions, if only to question the reliability of the quantitative models that are being used; systemic thinking should also be used in considering the question, raised above, of how an institution's assets and liabilities are to be adjusted over time when losses have caused a drop in equity capital. A supervisor who first is happy to see a life insurance company invest in the bonds of highly rated banks and then, in the crisis, finds that the insurance company is too heavily exposed to the risks of the banking sector and therefore ought to divest these bonds right away must himself be regarded as a systemic risk.

- The different regulatory and legal communities ought to think about robust and simple procedures for unwinding positions when a financial institution becomes insolvent. Ten years ago, one reason for not letting Long Term Capital Management (LTCM) go under right away was the fear of chaos created by the need to unwind a maze of contracts in multiple jurisdictions that had been concluded with hundreds of counterparties. Since then, as far as I can tell, no progress whatsoever has been made on the problem of how to deal with such an event.

\subsection{Towards a Reform of Capital Adequacy Regulation}

Turning to the approach that is taken to deal with the individual institution, I believe that there must be some component of capital regulation that is independent of whether the bank's risk model is right or not. This recommendation follows directly from the observation that the systemic risk that had been inherent in the excessive maturity transformation by conduits and SIVs could not have been anticipated by other institutions - or their risk models - because the requisite information had not been available. To be sure, exten- 
sions of reporting requirements and improvements in transparency will reduce this problem. However, as a matter of principle, I don't believe that statistical risk models will ever be fully appropriate. To some extent, taking account of this problem will be in the bank's own interest. To the extent that the bank's risk impose externalities on the rest of the financial systems, markets, institutions, and investors, this problem should also be considered in prudential regulation.

The Swiss National Bank has suggested that the issue might be dealt with by the imposition of a crude leverage ratio, i.e., a requirement that a bank's debt must not exceed $\mathrm{x} \%$ of a bank's balance sheet, without any attempt to distinguish how risky the bank's assets are. ${ }^{125}$ By contrast to the model-based approach, a leverage ratio regulation would set a fixed lower bound on the relation between the bank's equity capital and its balance sheet.

However, such a rule is very mechanical. More consideration must be given to its incidence over time, as the bank is adjusting assets and liabilities in response to current profits and losses. Here, a leverage ratio rule is likely to share the procyclical features of current capital regulation. If current losses reduce a bank's equity, the leverage ratio goes up, and the leverage ratio rule may require a divestiture of assets even though, in a panicky market, such a divestiture is detrimental to the bank as well as the financial system. ${ }^{126}$

The procyclical impact of such regulation is reduced if the leverage ratio is set at a low level or, equivalently, required capital is much higher than it has been in the recent past. If the maximum-leverage ratio is low, or the minimum-capital ratio is high, the impact of profits and losses on the bank's scope for action is relatively small. In more concrete terms: under the $8 \%$ capital ratio of Basel I, an additional dollar of equity provides the bank with the scope to make $12.50 \$$ of additional loans. If the capital ratio was $30 \%$, the scope for additional loans would be reduced to 3.33\$. Lower leverage ratios or higher equity ratios reduce the multiplier for reactions to changes in bank equity. ${ }^{127}$

At this point, the institutions concerned will protest that equity capital is expensive. I have yet to see a convincing argument showing that this protest is referring to social costs, rather than just the private costs to the bank manager of having to go to outside financiers and having to explain to them what he is doing and why his activities should merit their entrusting him with their money. ${ }^{128}$

125 See Bichsel and Blum (2001, 2005), Blum (2008).

126 Given that a maximum-leverage-ratio is the same as a minimum-equity-ratio, this observation cannot be surprising. The leverage ratio proposal can be interpreted as a kind of "Basel 0 " - capital regulation without risk weights.

127 The importance of this multiplier is stressed by Blum and Hellwig $(1995,1996)$ and Blum (1999).

128 On this point, see again King (1990) and Schaefer (1990). 
Going beyond marginal adjustments in the existing system of capital regulation, it would be desirable to reduce procyclical effects of the regulation directly by having a system of graduated interventions that allows for an adjustment of a bank's assets and liabilities over time in a non-mechanical fashion, moreover one that takes account of the effects of intervention on the financial system, as well as the bank. This would require a major reform of the system of capital regulation.

At this point, unfortunately, there is little prospect of such a reform. With all the intellectual and emotional capital that has been vested in it, the Basel Process seems to be progressing at full speed. The regulatory community is busy with the implementation of the new Basel Accord ("Basel II"), in which the crude weights that the 1988 Accord had used for credit risks are replaced by more sophisticated risk weights derived from external or internal credit ratings on the basis of quantitative models of credit risks. I consider it likely that the implementation of this new Basel Accord will actually strengthen the features of regulation that have contributed to making the current financial crisis as serious as it is. As yet, however, questions about the role of prudential regulation in the crisis do not seem to have raised substantial doubts about "Basel".

An underlying problem is that any system of banking regulation that is less mechanical than the one we currently have requires bank supervisors to take a more managerial role. Graduated responses to a bank's difficulties, taking account of the systemic environment, require an exercise of judgment. Banks do not like to subject themselves to such exercises of judgment from bureaucrats, and bureaucrats do not like to take responsibility for such exercises of judgment. At this point, bank supervisors do not even have the resources, in particular the qualified personnel, which would be needed for such a task.

Mechanical rules of prudential regulation are also popular because they are seen as being cheap to implement. To check whether a bank's balance sheet satisfies certain ratio requirements does not require much effort. Performing stress tests on the basis of a bank's quantitative risk model is more demanding, but not so much more, if the regulator doesn't have to develop the model himself. We can in fact think of the Basel Process as an endeavour to design a system of regulation that acknowledges the complexity of financial decision making in the real world while preserving the cheapness of a mechanical approach to banking regulation.

However, if I look at the current crisis, I wonder whether this isn't a case of being penny-wise and pound-foolish. By comparison to the costs of prudential supervision, the stakes for our economies, our societies, and, not least, our public budgets are enormous. They should warrant a larger investment of financial resources and of intellectual capital to design a system of prudential 
regulation that is better able to deal with the dynamics and the systemic aspects of risk in banking and finance. ${ }^{129}$

Open Access This article is distributed under the terms of the Creative Commons Attribution Noncommercial License which permits any noncommercial use, distribution, and reproduction in any medium, provided the original author(s) and source are credited.

\section{REFERENCES}

Akerlof, G. (1970), 'The Market for 'Lemons': Quality Uncertainty and the Market Mechanism', Quarterly Journal of Economics, 84, pp. 488-500.

Allen, F. and E. Carletti (2006), 'Credit Risk Transfer and Contagion', Journal of Monetary Economics, 53, pp. 89-111.

Allen, F. and E. Carletti (2008), 'Mark-to-Market Accounting and Cash-in-the-Market Pricing', Journal of Accounting and Economics, 45, pp. 358-378.

Allen, F. and D.M. Gale (2004a), 'Financial Intermediaries and Markets', Econometrica, 72, pp. 1023-1061.

Allen, F. and D.M. Gale (2004b), 'Financial Fragility, Liquidity, and Asset Prices', Journal of the European Economic Association, 2, pp. 1015-1048.

Allen, F. and D.M. Gale (2006), 'Systemic Risk and Regulation', in: M. Carey and R. Stulz (eds.), The Risks of Financial Institutions, University of Chicago Press, Chicago, pp. 341-375.

Baltensperger, E. and J. Dermine (1987), 'Banking Dregulation in Europe', Economic Policy, 4, pp. 63-109.

Bank for International Settlements (2007), '77th Annual Report: April 1, 2006 - March 31, 2007', Basel 2007.

Bank for International Settlements (2008), '78th Annual Report: April 1, 2007 - March 31, 2008', Basel 2008.

Ben-David, I. (2006/2008), 'Manipulation of Collateral Values by Borrowers and Intermediaries', Discussion Paper, Graduate School of Business, University of Chicago, http://search.ssrn.com/ sol3/papers.cfm?abstract_id=991387.

Benston, G.J., M. Carhill and B. Olasov (1991), 'The Failure and Survival of Thrifts: Evidence from the Southeast', in: R. Hubbard (ed.), Financial Markets and Financial Crises, University of Chicago Press, Chicago, pp. 305-384.

Berglöf, E. and H. Sjögren (1998), 'Combining Arms' Length and Control-Oriented Finance: Evidence From Main-Bank Relationships in Sweden’, in: K.J. Hopt, H. Kanda, M.J. Roe, E. Wymeersch, and S. Prigge (eds.), Comparative Corporate Governance: The State of the Art and Emerging Research, Clarendon Press, Oxford.

129 For an earlier plea along these lines, see Hellwig (1995). The argument there points to the fact that some managerial involvement of supervisors - or representatives of deposit insurance agencies - is justified by the fact that, if things go wrong, the damage will at least partly be borne by depositors or the deposit insurance agency. On this point, see also Dewatripont and Tirole (1994). 
Bernanke, B.S. (2008), 'Mortgage Delinquencies and Foreclosures, Speech at the Columbia Business School 32nd Annual Dinner', http://www.federalreserve.gov/newsevents/speech/ Bernanke20080505a.htm.

Bernanke, B.S. and C. Lown (1991), 'The Credit Crunch', Brookings Papers on Economic Activity, 2, pp. 205-247.

Bichsel, R. and J. Blum (2001), 'Gearing Ratios', Swiss National Bank, Quarterly Bulletin, 3, pp. $48-58$.

Bichsel, R. and J. Blum (2005), 'Capital Regulation of Banks: Where Do We Stand and Where Are We Going?', Swiss National Bank, Quarterly Bulletin, 4, pp. 42-51.

Blattner, N. (1995), 'Panel Discussion - Statements and Comments', Schweizerische Zeitschrift für Volkswirtschaft und Statistik/Swiss Journal of Economics and Statistics, 131, pp. 819-830, http:// www.sjes.ch/papers/1995-IV-18.pdf.

Blum, J.M. (1999), 'Do Capital Adequacy Requirements Reduce Risks in Banking?', Journal of Banking and Finance, 23, pp. 755-771.

Blum, J.M. (2008), 'Why 'Basel II' May Need a Leverage Ratio Restriction', Journal of Banking and Finance, 32, pp. 1699-1707.

Blum, J.M. and M. Hellwig (1995), 'The Macoeconomic Implications of Capital Adequacy Requirements for Banks', European Economic Review, 39, pp. 739-749.

Blum, J.M. and M. Hellwig (1996), 'Die makroökonomischen Wirkungen von Eigenkapitalanforderungen für Banken', in: D. Duwendag (ed.), Finanzmärkte, Finanzinnovationen und Geldpolitik, Schriften des Vereins für Socialpolitik, NF 242, Duncker und Humblot, Berlin, pp. 41-71.

Boyd, J. and M. Gertler (1994), 'The Role of Large Banks in the Recent US Banking Crisis', Federal Reserve Bank of Minneapolis Quarterly Review, 18, pp. 2-21.

Calomiris, C.W. (1999), 'Market-Based Banking Supervision', The Financial Regulator, 4, pp. 33-36.

Calomiris, C.W. and C.M. Kahn (1991), 'The Role of Demandable Debt in Structuring Optimal Banking Arrangements', American Economic Review, 81, pp. 497-513.

Carosio, G. (1990), 'Problems of Harmonization of the Regulation of Financial Intermediation in the European Community', European Economic Review, 34, pp. 578-586.

Case, K.E., J.M. Quigley and R.J. Shiller (2005), 'Comparing Wealth Effects: The Stock Market versus the Housing Market', Advances in Macroeconomics, 5(1), Article 1, available at: http:// www.bepress.com/bejm/advances/vol5/iss1/art1.

Chomsisengphet, S. and A. Pennington-Cross (2006), 'The Evolution of the Subprime Mortgage Market', Federal Reserve Bank of St. Louis Review, 88, pp. 31-56.

Crockett, A. (2007), 'The Evolution and Regulation of Hedge Funds', in: Banque de France (ed.), Financial Stability Review - Special Issue on Hedge Funds, April 2007, pp. 19-28, http://www. banque-france.fr/gb/publications/rsf/rsf_042007.htm.

Curry, T. and L. Shibut (2000). 'The Costs of the Savings and Loan Crisis: Truth and Consequences', FDIC Banking Review, 13, pp. 26-35.

Demyanyk, Y. and O. Van Hemert (2008), Understanding the Subprime Mortgage Crisis, mimeo. Stern School of Business, New York University, http://ssrn.com/abstract=1020396.

Dewatripont, M. and J. Tirole (1994), 'The Prudential Regulation of Banks'. MIT-Press, Cambridge, USA.

Diamond, D.W. (1984), 'Financial Intermediation and Delegated Monitoring', Review of Economic Studies, 51, pp. 393-414. 
DiMartino, D. and J.V. Duca (2007), 'The Rise and Fall of Subprime Mortgages', Economic Letter: Insights from the Federal Reserve Bank of Dallas, 2, pp. 11.

Dodd, R. (2007), 'Subprime: Tentacles of a Crisis', Finance and Development, 44, Nr. 4, pp. 15-19, http://www.imf.org/external/pubs/ft/fandd/2007/12/dodd.htm.

Dodd, R. and P. Mills (2008), 'Outbreak: U.S. Subprime Contagion', Finance and Development, 45 , Nr. 2, pp. 14-18, http://www.imf.org/external/pubs/ft/fandd/2008/06/dodd.htm.

Duffie, D. (2007), Innovations in Credit Risk Transfer: Implications for Financial Stability mimeo. Stanford University, Stanford, CA, http://www.stanford.edu/duffie/BIS.pdf.

Englund, P. (1990), 'Financial Deregulation in Sweden', European Economic Review, 34, pp. 385-393.

Englund, P. (1999), 'The Swedish Banking Crisis: Roots and Consequences', Oxford Review of Economic Policy, 15, pp. 80-97.

Financial Crimes Enforcement Network: Regulatory Policy and Programs Division, Office of Regulatory Analysis (2006), 'Mortgage Fraud: An Industry Assessment Based on Suspicious Activity Report Analysis', Washington, http://www.fincen.gov/news_room/rp/reports/pdf/ MortgageLoanFraud.pdf.

Franke, G. and J.P. Krahnen (2006), 'Default Risk Sharing Between Banks and Markets: The Contribution of Collateralized Debt Obligations', in: M. Carey and R. Stulz (eds.), The Risks of Financial Institutions, University of Chicago Press, Chicago, pp. 603-631.

Gale, D.M. (1992), 'Standard Securities', Review of Economic Studies, 59, pp. 731-755.

Hakenes, H. and I. Schnabel (2008), Credit Risk Transfer in Banking Markets with Hard and Soft Information, mimeo. Max Planck Institute for Research on Collective Goods, Bonn.

Hellwig, M. (1994a), 'Liquidity Provision, Banking, and the Allocation of Interest Rate Risk', European Economic Review, 38, pp. 1363-1389.

Hellwig, M. (1994b), 'Banking and Finance at the End of the Twentieth Century', WWZ Discussion Paper 9426, University of Basel, Switzerland.

Hellwig, M. (1995), 'Systemic Aspects of Risk Management in Banking and Finance', Schweizerische Zeitschrift für Volkswirtschaft und Statistik/Swiss Journal of Economics and Statistics, 131, pp. 723-737, http://www.sjes.ch/papers/1995-IV-9.pdf.

Hellwig, M. (1996), 'Capital Adequacy Rules as Instruments for the Regulation of Banks', Schweizerische Zeitschrift für Volkswirtschaft und Statistik/Swiss Journal of Economics and Statistics, 132, pp. 609-612, http://www.sjes.ch/papers/1996-IV-6.pdf.

Hellwig, M. (1998a), 'Banks, Markets, and the Allocation of Risks in an Economy', Journal of Institutional and Theoretical Economics, 154, pp. 328-345.

Hellwig, M. (1998b), 'Systemische Risiken im Finanzsektor', Zeitschrift für Wirtschafts- und Sozialwissenschaften, Beiheft 7, pp. 123-151.

Hellwig, M. (2005), 'Market Discipline, Information Processing, and Corporate Governance', in: K.J. Hopt, E. Wymeersch, H. Kanda and H. Baum (eds.), Corporate Governance in Context: Corporations, States, and Markets in Europe, Japan, and the US, Oxford University Press, Oxford, UK, pp. 379-402.

Hellwig, M. (2007), 'Switzerland and Euroland: European Monetary Union, Monetary Stability and Financial Stability', in: Swiss National Bank (ed.), The Swiss National Bank 1907-2007, Neue Zürcher Zeitung Publishing, Zürich, pp. 741-779.

Hellwig, M. and M. Staub (1996), 'Report on a Panel "Capital Requirements for Market Risks Based on Inhouse Models - Aspects of Quality Assessment"', Swiss Journal of Economics and Statistics, 132, pp. 755-776, http://www.sjes.ch/papers/1996-IV-22.pdf. 
Hendershott, P.H. and J.D. Shilling (1991), 'The Continued Interest-Rate Vulnerability of the Thrifts', in: R. Hubbard (ed.), Financial Markets and Financial Crises, Chicago, University of Chicago Press, pp. 259-282.

Holmström, B. and P.R. Milgrom (1991), 'Multitask Principal-Agent Analyses: Incentive Contracts, Asset Ownership and Job Design', Journal of Law, Economic sand Organization, 7(suppl.), pp. 24 52.

International Monetary Fund (2007), 'Market Developments and Issues, Global Financial Stability Report', Washington, DC, April 2007, http://www.imf.org/External/Pubs/FT/GFSR/2007/01/ text.pdf.

International Monetary Fund (2008a), 'Containing Systemic Risks and Restoring Financial Soundness, Global Financial Stability Report', April 2008, http://www.imf.org/External/Pubs/ FT/GFSR/2008/01/index.htm.

International Monetary Fund (2008b), 'Financial Stress and Deleveraging: Macro-Financial Implications and Policy, Global Financial Stability Report', October 2008, http://www.imf.org/ External/Pubs/FT/GFSR/2008/02/index.htm.

Jensen, M. C. and W.H. Meckling (1976), 'Theory of the Firm: Managerial Behavior, Agency Costs and Ownership Structure', Journal of Financial Economics, 3, pp. 305-360.

Kane, E.J. (1985), 'The Gathering Crisis in Federal Deposit Insurance'. MIT-Press, Cambridge, USA.

Kane, E.J. (1989), The $S \&$ L Insurance Mess: How Did It Happen?. Urban Institute Press, Washington, DC.

Kiff, J. and P. Mills (2007), 'Money for Nothing and Checks for Free: Recent Developments in U.S. Subprime Mortgage Markets', International Monetary Fund Working Paper 07/188.

King, M. (1990), 'International Harmonization of the Regulation of Capital Markets', European Economic Review, 34, pp. 569-577.

Kuran, T. (1995), Private Truths, Public Lies - The Social Consequences of Preference Falsification. Harvard University Press, Cambridge, Massachusetts.

Mélitz, J. (1990), 'Financial Deregulation in France', European Economic Review, 34, pp. $394-402$.

Myers, S.C. and R.G. Rajan (1998), 'The Paradox of Liquidity', Quarterly Journal of Economics, 113, pp. 733-771.

OECD (1992), Banks Under Stress. OECD Publications, Paris.

Peltzman, S. (1975), 'The Effects of Automobile Safety Regulation', Journal of Political Economy, 83, pp. 677-725.

Reid, M. (1982), The Secondary Banking Crisis 1973-1975: Its Causes and Course. Macmillan, London.

Rochet, J.-C. (1992), 'Capital Requirements and the Behaviour of Commercial Banks', European Economic Review, 36, pp. 1137-1178.

Rona-Tas, A. and S. Hiß (2008), 'The Art of Corporate and the Science of Consumer Credit Rating', Paper Presented at the 38th World Congress of the International Institute of Sociology.

Schaefer, S.M. (1990), 'The Regulation of Banks and Securities Firms', European Economic Review, 34, pp. 587-597.

Schnabel, I. and H.S. Shin (2004), 'Liquidity and Contagion: The Crisis of 1763', Journal of the European Economic Association, 2, pp. 929-968.

Schütz, D. (1998), Der Fall der UBS. Weltwoche-Verlag, Zürich.

Schwartz, E.S. and W. N. Torous (1991), 'Caps on Adjustable Rate Mortgages: Valuation, Insurance, Hedging', in R. Hubbard (ed.), Financial Markets and Financial Crises, University of Chicago Press, Chicago, pp. 283-302. 
Shleifer, A. (2000), Inefficient Markets: An Introduction to Behavioral Finance. Oxford University Press, Oxford, UK.

Slacalek, J. (2006), 'What Drives Personal Consumption? The Role of Housing and Financial Wealth', Discussion Paper 647, Deutsches Institut für Wirtschaftsforschung, Berlin, http:// www.diw.de/documents/publikationen/73/44944/dp647.pdf.

Staub, M. (1998a), 'Inter-Banken-Kredite und systemisches Risiko', Schweizerische Zeitschrift für Volkswirtschaft und Statistik/Swiss Journal of Economics and Statistics, 134, pp. 193-230, http:// www.sjes.ch/papers/1998-II-5.pdf.

Staub, M. (1998b), 'The Term Structure of Interest Rates and the Swiss Regional Banking Crisis - Empirical Evidence and its Limits', Schweizerische Zeitschrift für Volkswirtschaft und Statistik/Swiss Journal of Economics and Statistics, 134, pp. 655-683, http://www.sjes.ch/papers/ 1996-IV-19.pdf.

Staub, M. (1998c), 'Report on a Panel "International Contagion: What Is It and What Can be Done Against It?", Schweizerische Zeitschrift für Volkswirtschaft und Statistik/Swiss Journal of Economics and Statistics, 134, pp. 715-721, http://www.sjes.ch/papers/1998-IV-23.pdf.

Stiglitz, J.E. and A.M.Weiss (1981), 'Credit Rationing in Markets with Imperfect Information', American Economic Review, 71, pp. 393-410.

Takala, K., und M.Virén. (1995), 'Bankruptcies, Indebtedness and the Credit Crunch', Bank of Finland Discussion Paper No. 28/95, Helsinki.

UBS (2008), 'Shareholder Report on UBS's Writedowns', http://www.ubs.com/1/e/investors/ shareholderreport/remediation.html.

Useem, M. (1993), Executive Defense: Shareholder Power and Corporate Reorganization. Harvard University Press, Cambridge.

Vives, X. (1990), 'Deregulation and Cmpetition in Spanish Banking', European Economic Review, 34, pp. 403-411.

Wuffli, P. (1995), 'Comment on the Paper by Professor Hellwig, Systemic Aspects of Risk Management in Banking and Finance', Schweizerische Zeitschrift für Volkswirtschaft und Statistik/Swiss Journal of Economics and Statistics, 131, pp. 139-140. 